medRxiv preprint doi: https://doi.org/10.1101/2021.11.30.21266988; this version posted December 5, 2021. The copyright holder for this preprint (which was not certified by peer review) is the author/funder, who has granted medRxiv a license to display the preprint in

It is made available under a CC-BY-NC 4.0 International license .

\title{
Non-muscle Invasive Bladder Cancer Molecular Subtypes Predict Differential Response to Intravesical Bacillus Calmette-Guérin
}

\section{Authors:}

Florus C. de Jong ${ }^{1}$, Teemu D. Laajala ${ }^{2,3}$, Robert F. Hoedemaeker ${ }^{4}$, Kimberley R. Jordan ${ }^{5}$, Angelique C.J. van der Made ${ }^{6}$, Egbert R. Boevé ${ }^{7}$, Deric K.E. van der Schoot ${ }^{8}$, Bart Nieuwkamer ${ }^{9}$, Emiel A.M. Janssen ${ }^{10}$, Tokameh Mahmoudi ${ }^{1,6}$, Joost L. Boormans ${ }^{1}$, Dan Theodorescu ${ }^{11,{ }^{*}}$, James C. Costello ${ }^{2,{ }^{*}}$, Tahlita C.M. Zuiverloon ${ }^{1,{ }^{*}}$

\section{Affiliations:}

${ }^{1}$ Department of Urology, Erasmus University Medical Center, Erasmus MC Cancer Institute, Rotterdam, the Netherlands

${ }^{2}$ Department of Pharmacology, University of Colorado Anschutz Medical Campus, Aurora, CO, USA

${ }^{3}$ Department of Mathematics and Statistics, University of Turku, Turku, Finland

${ }^{4}$ Pathan, Pathological Laboratory, Rotterdam, the Netherlands

${ }^{5}$ Department of Immunology and Microbiology, University of Colorado Anschutz Medical Campus, Aurora, CO, USA

${ }^{6}$ Department of Pathology, Erasmus MC Cancer Institute, Rotterdam, the Netherlands

${ }^{7}$ Department of Urology, Franciscus Gasthuis \& Vlietland, Rotterdam, the Netherlands

${ }^{8}$ Department of Urology, Amphia, Breda, The Netherlands

${ }^{9}$ Department of Urology, Reinier de Graaf Gasthuis, Delft, the Netherlands

${ }^{10}$ Department of Pathology, Stavanger University Hospital, Stavanger, Norway

${ }^{11}$ Samuel Oschin Comprehensive Cancer Institute, Cedars-Sinai, Los Angeles, USA

One Sentence Summary: Molecular subtypes are predictive of response to intravesical Bacillus Calmette-Guérin immunotherapy in non-muscle invasive bladder cancer.

Keywords / Mesh: BCG, biomarker, bladder cancer, immunotherapy, transcriptome, tumor microenvironment, tumor progression, urothelial cancer

\section{* Corresponding authors:}

Dan Theodorescu, Cedars-Sinai Medical Center. Address: 8700 Beverly Blvd., OCC Mezz C2002, Los Angeles, CA 90048. Phone: Phone: +1-310-423-8431; E-mail:

dan.theodorescu@cshs.org

James C. Costello, University of Colorado, Anschutz Medical Campus. Address: 12801 East 17th Ave, Aurora CO 80045. Room: RC1-South, L18-6114. Phone: +1-303-724-8619; Email: james.costello@cuanschutz.edu

T.C.M. Zuiverloon, Erasmus MC Cancer Institute. Address: Dr. Molewaterplein 40, Room Be-304, 3015 GD, Rotterdam, The Netherlands. Phone: +31-107043059; E-mail: t.zuiverloon@erasmusmc.nl 
medRxiv preprint doi: https://doi.org/10.1101/2021.11.30.21266988; this version posted December 5, 2021. The copyright holder for this preprint (which was not certified by peer review) is the author/funder, who has granted medRxiv a license to display the preprint in It is made available under a CC-BY-NC 4.0 International license .

\section{Numbers:}

Title word count: 13

Word count summary: 218

Word count manuscript ex. methods, incl legends: 6003

Methods: 1972

Tables: 1

Figures: 5

Supplementary Materials: yes

Supplementary Tables: 7

Supplementary Figures: 9

Supplementary Data: 3

\section{Abbreviations}

$\mathrm{BC}=$ bladder cancer

$\mathrm{BCG}=$ Bacillus Calmette-Guérin

$\mathrm{BRS}=\mathrm{BCG}$ response subtypes

$\mathrm{CIS}=$ carcinoma in situ

$\mathrm{ECM}=$ extracellular matrix

EMT = epithelial-to-mesenchymal transition

HR-NMIBC = high-risk non-muscle invasive bladder cancer

$\mathrm{HG}=$ high-grade

$\mathrm{HR}=$ high-risk

$\mathrm{HHR}=$ very high-risk

$\mathrm{LVI}=$ lymphovascular invasion

$\mathrm{MIBC}=$ muscle invasive bladder cancer

NMIBC = non-muscle invasive bladder cancer

PFS $=$ progression-free survival

re-TURBT = repeat transurethral resection of the bladder tumor

$\mathrm{RFS}=$ recurrence-free survival

$\mathrm{RC}=$ radical cystectomy

TAM = tumor associated macrophages

TME = tumor microenvironment

TURBT = transurethral resection of the bladder tumor

$\mathrm{VH}=$ variant histology 
medRxiv preprint doi: https://doi.org/10.1101/2021.11.30.21266988; this version posted December 5, 2021. The copyright holder for this preprint (which was not certified by peer review) is the author/funder, who has granted medRxiv a license to display the preprint in It is made available under a CC-BY-NC 4.0 International license .

\section{Summary}

2 The recommended treatment for patients with high-risk non-muscle invasive bladder cancer 3 (HR-NMIBC) is tumor resection followed by adjuvant Bacillus Calmette-Guérin (BCG) bladder 4 instillations. However, only $50 \%$ of patients benefit from this therapy. In case of progression 5 to advanced disease, patients must undergo a radical cystectomy with significant morbidity 6 and have a poor clinical outcome. Identifying tumors least likely to respond to BCG can 7 translate into alternative treatments, such as early radical cystectomy or novel targeted or 8 immunotherapies. Here we present molecular profiling of 132 BCG-naive, HR-NMIBC 9 patients, and 44 post-BCG recurrences (34 matched), which uncovered three distinct BCG 10 Response Subtypes (BRS1-3). Patients with BRS3 tumors have reduced recurrence and 11 progression-free survival compared to BRS1-2. BRS3 tumors expressed high EMT-basal 12 markers and had an immunosuppresive profile, which was confirmed with spatial proteomics. 13 Tumors which recurred post-BCG were enriched for BRS3. BRS stratification was validated in 14 a second cohort of 151 BCG-naive HR-NMIBC patients and the molecular subtypes 15 outperformed guideline recommended risk stratification based on clinicopathological 16 variables. For clinical application, we validated that a commercially approved assay was able 17 to accurately predict BRS3 tumors (AUROC 0.86). Our findings provide a potential clinical tool 18 for improved identification of HR-NMIBC patients at the highest risk of progression, which can be used to select patients for early radical cystectomy or novel subtype-directed therapies. 
medRxiv preprint doi: https://doi.org/10.1101/2021.11.30.21266988; this version posted December 5,2021 . The copyright holder for this preprint (which was not certified by peer review) is the author/funder, who has granted medRxiv a license to display the preprint in

It is made available under a CC-BY-NC 4.0 International license .

\section{Introduction}

Non-muscle invasive bladder cancer (NMIBC) accounts for $75 \%$ of all bladder tumors [1]. The recommended treatment for high-risk NMIBC (HR-NMIBC) consists of a transurethral resection of the bladder tumor (TURBT) and adjuvant intravesical Bacillus Calmette-Guérin $(B C G)$ instillations [1]. Initial treatment response to $B C G$ is excellent, yet the long-term efficacy is moderate as HR-NMIBC patients have a $50 \%$ risk of developing recurrent disease within 5 years [2]. Furthermore, a $20 \%$ risk of progression to advanced disease is observed, which is associated with high mortality [1,3]. Patients with HR-NMIBC where a tumor recurs or progresses have been exposed to unnecessary BCG toxicity, a delay in radical treatment and have reduced survival $[4,5]$. Therefore, it is critical to identify patients, who are at risk for treatment failure with standard-of-care, prior to initiation of BCG therapy $[6,7]$. These patients might be candidates for an early radical cystectomy $(R C)$ procedure, which although negatively affects quality of life, has excellent long-term outcomes [8]. Additionally, novel treatment modalities are urgently needed because of an ongoing global BCG shortage [9].

The genetic make-up of tumors can dictate therapeutic response, and it is hypothesized that molecular profiling of HR-NMIBC may reveal mechanisms of response to BCG [10, 11]. Several studies from whole-transcriptome analyses of NMIBC have led to clustering-based classification systems and identification of predictive signatures of disease progression [1216]. Dyrskjot et al. prospectively validated a 12-gene expression signature that corresponded to progression in HR-NMIBC. However, the progression signature had limited added value compared to the standard clinicopathological risk stratification. Recently, a study identified five molecular subtypes in 73 HR-NMIBC patients treated with BCG, however none of the subtypes corresponded to progression-free survival [17]. A major drawback of NMIBC molecular subtyping studies has been the lack of BCG-treated patients, preventing the identification of specific molecular signatures predictive of BCG treatment response. Moreover, studies were hampered by a lack of detailed information on BCG treatment and a lack of patients who experienced progressive disease. In addition, a user-friendly tool for subtype identification has not yet been developed. Because of these caveats, the translational impact of molecular subtypes thus far remained limited.

In this study, we leverage two large and fully annotated cohorts of HR-NMIBC patients treated with BCG and with clinical follow-up to define three molecular subtypes that associate with clinical outcomes. The molecular subtypes have unique features that correlated with differential response to BCG. We identified an aggressive EMT-basal immunosuppressive subtype (BCG response subtype 3 (BRS3) and we show that BRS3 is the dominant subtype in post-BCG recurrences. We demonstrate that subtyping improved the guideline recommended risk stratification and that a commercially available pathway-assay was able to accurately identify BRS3 tumors for clinical utility. Finally, we identified druggable genes and pathways associated with resistance to immunotherapy in post-BCG recurrences as candidate targets for bladder-sparing therapies in HR-NMIBC patients. 
medRxiv preprint doi: https://doi.org/10.1101/2021.11.30.21266988; this version posted December 5, 2021. The copyright holder for this preprint (which was not certified by peer review) is the author/funder, who has granted medRxiv a license to display the preprint in

It is made available under a CC-BY-NC 4.0 International license .

\section{Results}

\section{HR-NMIBC molecular subtypes with divergent clinical outcome after BCG}

To identify gene signatures predictive of clinical outcome, we performed whole-transcriptome sequencing of two HR-NMIBC patient cohorts: discovery Cohort A, $n=132$ pre-BCG and $n=44$ post-BCG tumors (34 matched tumors) and validation Cohort $B=151$ pre-BCG tumors. $A$ synopsis of the study design is shown in Fig. 1A. Detailed information on resources and patient inclusion can be found in the methods section and all clinicopathological information and follow-up data for both cohorts is listed in Table S1. No differences in progression-free survival (PFS) were observed between Cohort A and B (Fig. S1A).

To determine the presence and robustness of molecular subtypes, we split Cohort $A$ at a 3:1 ratio into a training and testing set. We applied consensus clustering on the top 2000 protein coding genes with the most varying expression in the training set to identify three subtypes with differential risk of progression (Fig. S1B-C). To prevent bias caused by immune populations based on gene expression analyses, all clustering in this study was performed with removal of genes predictive of immune cell populations. A nearest shrunken centroid classifier was then trained and used to predict subtypes in the testing set. Based on estimated PFS and overlapping pathway activity, the presence of three molecular subtypes was confirmed in the testing set (Fig. S1D-E). Subtypes were called BCG Response Subtype 1, 2 and 3 (BRS). After cross validation to estimate the robustness of the BRS in the training and testing set, we retrained the model on the full dataset of Cohort A (Fig. S1F), and set out to investigate the clinical and molecular features of the BRS. Patients with BRS3 tumors had a significantly worse PFS (Fig. 1A) than BRS1/2, with a 2 -year PFS of $61 \%$ for BRS3 versus $78 \%$ for BRS2 and $83 \%$ for BRS1. Differential pathways associated with the BRS in Cohort A are illustrated in Fig. 1B), the top 30 non-synonymous SNVs are in Fig. S2 (Table S2). BRS3 patients showed increased EMT pathway activity, and were significantly enriched for mutations associated with the extracellular matrix (ECM) (e.g. AEBP1), which might explain the higher risk of progression in BRS3 patients.

Next, we set out to validate the BRSs clinical outcome and molecular features. To this end, we performed whole-transcriptome sequencing on a second HR-NMIBC patient cohort (Cohort B, $n=151$ pre-BCG tumors; see Table S1 for patient information) and used the BRS classifier trained on Cohort A to predict molecular subtypes in Cohort B. Fig. S3 illustrates highly similar pathway activity per BRS in patients from Cohort B vs A. Here too, survival analysis showed that patients with BRS3 tumors had the worst PFS (2-year PFS 94\% for BRS1, 87\% for BRS2 and 67\% for BRS3, Fig. 1A). To explore how gene expression of the BRSs would overlap with previously published NMIBC and MIBC subtypes, we applied the BRS classifier to UROMOL21 and TCGA cohorts [13, 18]. In UROMOL21, BRS3 predicted tumors were overlapping with the more aggressive Class 2A/B NMIBC subtype, while the less aggressive Class $1 / 3$ tumors were more likely to be $B R S 1 / 2(p<0.01$, Fig. S4A). Although UROMOL21 contained patients that were not primary HR-NMIBC or treated with $\geq 5$ instillations of BCG, we did observe overlapping gene signatures and a similar BRS stratification, which was specifically evident for stage T1 HR-NMIBC (Fig. S4B). In the TCGA cohort, BRS1/2 tumors were predominantly luminal papillary $(p<0.001)$. BRS3 tumors were more frequently luminal infiltrated and basal/squamous $(p<0.001)$ (Fig. S4C), and these tumors are known to be more aggressive. As a final step, we validated pathway activity in a second independent dataset with BCG-treated, HR-NMIBC patients (Fig. S4D). BRS2 (MYC high) seemed to associate with T1-MYC, while BRS3 (basal high) did not contain any T1-Lum tumors. No association with PFS was observed, but only eight patients progressed [17]. 
medRxiv preprint doi: https://doi.org/10.1101/2021.11.30.21266988; this version posted December 5, 2021. The copyright holder for this preprint (which was not certified by peer review) is the author/funder, who has granted medRxiv a license to display the preprint in

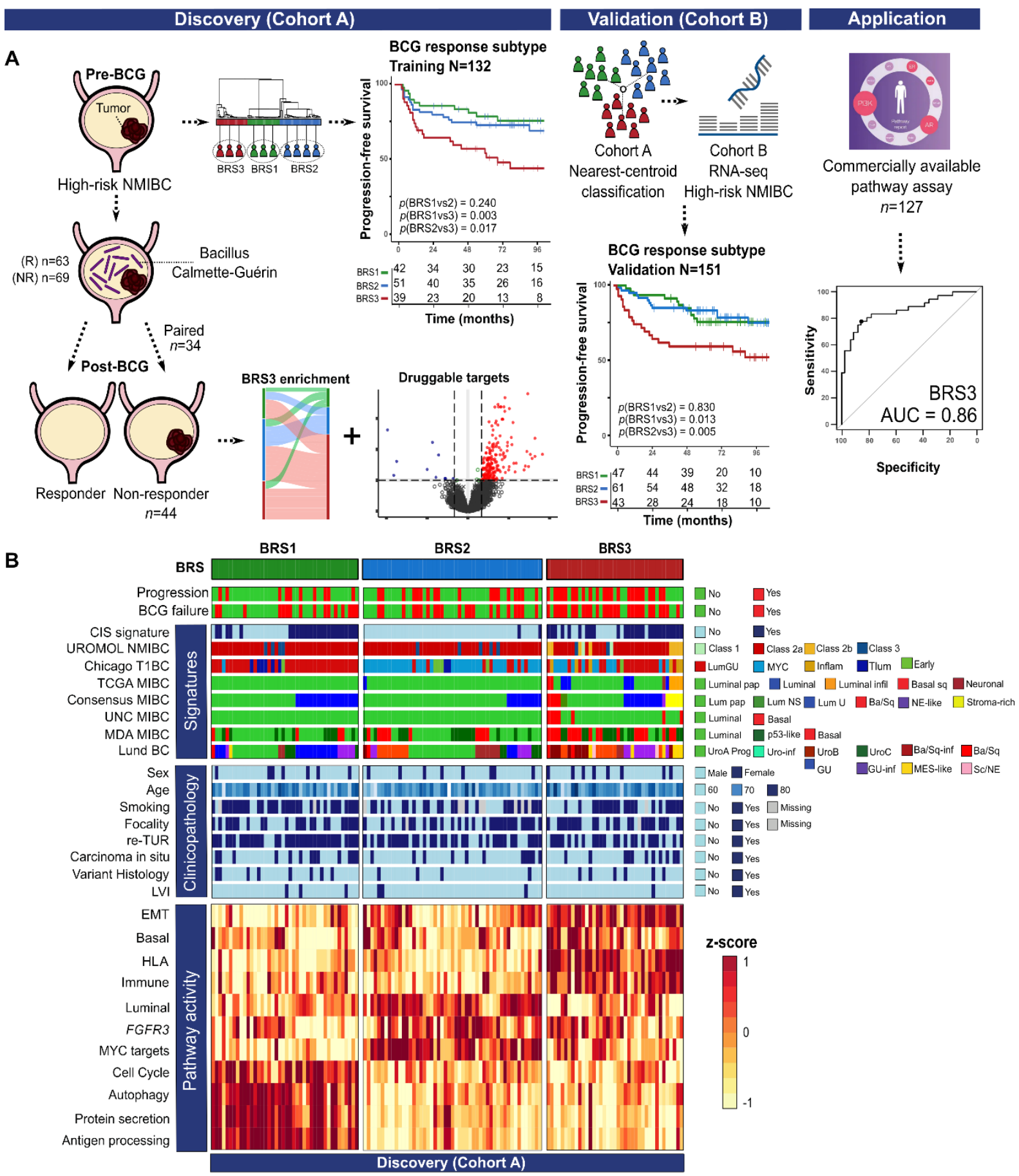

Fig. 1. Study design, progression-free survival (PFS) and gene signatures of patients with high-risk NMIBC according to BCG response subtypes (BRS). A: RNA-seq was performed on Cohort A: $n=132$ pre-BCG, high-risk NMIBC tumors ( $n=63$ BCG-responders [R] vs. $n=69$ BCG non-responders [NR]). From the BCG NR, $n=44$ post-BCG tumors were also sequenced ( $n=34$ matched pre- and post BCG samples $+n=10$ non-matched). Paired analysis showed enrichment of BRS3 post-BCG and identified candidate druggable genes. Cohort B consisted of $n=151$ pre-BCG, high-risk NMIBC tumors ( $n=88$ BCG-responders vs. $n=63$ BCG non-responders). For both cohorts, PFS is stratified according to BRSs. Finally, a qPCR pathway assay had an AUC of 0.86 in identifying BRS3 patients. B: Heatmap of gene signatures and annotation of Cohort A grouped according to BRS. From top to bottom: 1) Progression to MIBC; 2) BCG response; 3) carcinoma in situ signature [19];4) UROMOL21 NMIBC subtypes [13]; 5) T1BC subtypes [17]; 6) TCGA MIBC subtypes [18]; 7) Consensus MIBC subtypes [17]; 8) UNC MIBC subtypes [20]; 9) MDA MIBC subtypes [21]; 10) Lund BC subtypes [14]; 11) Clinicopathological parameters associated to pre-BCG tumors; 12) $B R S$ signatures based on mean gene expression of selected genes (details in methods). Abbreviations: $B C G=$ Bacillus Calmette-Guérin; (N)MIBC = (non-)muscle-invasive bladder cancer.

119 Last, we investigated whether clinicopathological parameters could explain differences 120 between subtypes in the combined dataset (Table 1), or in Cohort A or B separately (Table S1A-B). Due to the probability of understaging in $10 \%$ of T1 HR-NMIBC and thus BCG 
medRxiv preprint doi: https://doi.org/10.1101/2021.11.30.21266988; this version posted December 5, 2021. The copyright holder for this preprint (which was not certified by peer review) is the author/funder, who has granted medRxiv a license to display the preprint in

It is made available under a CC-BY-NC 4.0 International license.

treatment failure, guidelines recommend that patients undergo a re-TURBT prior to initiation of BCG treatment [22]. Although a re-TURBT itself was not associated with PFS $(H R=1.0$, $p=0.97$ ), the proportion of patients who had undergone a re-TURBT was higher in BRS1 patients, who had a favorable outcome. We recognize that a difference in re-TURBTs might lead to a decreased risk of treatment failure. Therefore, we repeated clustering in only patients who received a re-TURBT $91 / 132(69 \%)$. Neither risk stratification, nor expression patterns differed between patients with and without re-TURBT (Fig. S5), thus we concluded that a reTURBTs did not affect the prognostic capability of the BRS. In summary, we discovered three molecular subtypes (BRS) of HR-NMIBC and showed their clinical relevance and consistency in pathway activity across multiple patient cohorts.

\section{BRS3 is an aggressive molecular subtype of HR-NMIBC}

The BRS clearly delineated a group of patients with a high risk of progression (BRS3). Unraveling the underlying molecular characteristics that drive BRS3 could explain differences in clinical outcome and possibly lead to identification of candidate druggable targets for novel treatments. Based on the overlapping gene expression patterns and PFS, we combined Cohort A and B ( $n=283$ ). Differential gene expression (DGE) analysis showed that BRS3 tumors had overexpression of basal and EMT activation markers (CD44, KRT5/6, DDR2, VIM, SNA11, ZEB1/2 and TWIST1). Furthermore, BRS3 tumors were characterized by overexpression of immune suppressive genes, including immune-checkpoint genes $(P D$ 1/PD-L1 and CTLA-4), T regulatory markers (T regs; CD4/CD25/FOXP3), myeloid derived suppressor cell (MDSC) markers, colony stimulating factors (CSFS) and chemokines (CXCLS and CXCRs), which have been implicated in BCG treatment failure [23]. A full list of differentially expressed genes is reported in Table S3.

We then analyzed pathways associated with distinct subtypes. Individual genes upon which the BRS pathway activity is based are listed in Fig. S6A. In BRS3 tumors, gene set enrichment analysis identified pathways known to be associated with cancer progression, such as EMT, Notch, MAPK and angiogenesis (Fig. 2A/B). Moreover, immune-related pathways were strongly enriched, e.g., complement, IL6-JAK-STAT3 and IL2-STAT5 (Fig. 2A/B). Complete results are listed in Table S4.

Regulon analysis using Viper was performed to allow for computational inference of protein activity based on downstream target gene expression patterns in each subtype [24]. Regulons comprising the top 150 most varying transcriptional regulators for which small molecular inhibitors are available are shown for the three HR-NMIBC subtypes (Fig. 2C) [25]. These genes may prove to be attractive candidates for subtype-specific drug targeting. Several regulatory genes have previously been identified as important genes driving bladder cancer (BC). These genes have been grouped according to BRS in Fig. S6B [18]. We observed low $R B 1$ and TP63 in BRS3 tumors, which is often seen in aggressive BC [26]. We confirmed activity of EMT-associated regulons (ZEB2, TWIST2 and SNAI3), and enrichment of regulators related to MDSCs and B cells (CD14, CD86), T regs (BATF3, IL10, IL 16, FOXP3) and T cell polarization (STAT1/STAT4 and TBX21) (Table S4). Taken together, BRS3 tumors were enriched for regulators associated with EMT activation, a basal phenotype and immune checkpoint proteins, and these results associate biological features of BRS3 tumors with the corresponding poor clinical outcome. 
medRxiv preprint doi: https://doi.org/10.1101/2021.11.30.21266988; this version posted December 5, 2021. The copyright holder for this preprint (which was not certified by peer review) is the author/funder, who has granted medRxiv a license to display the preprint in

A

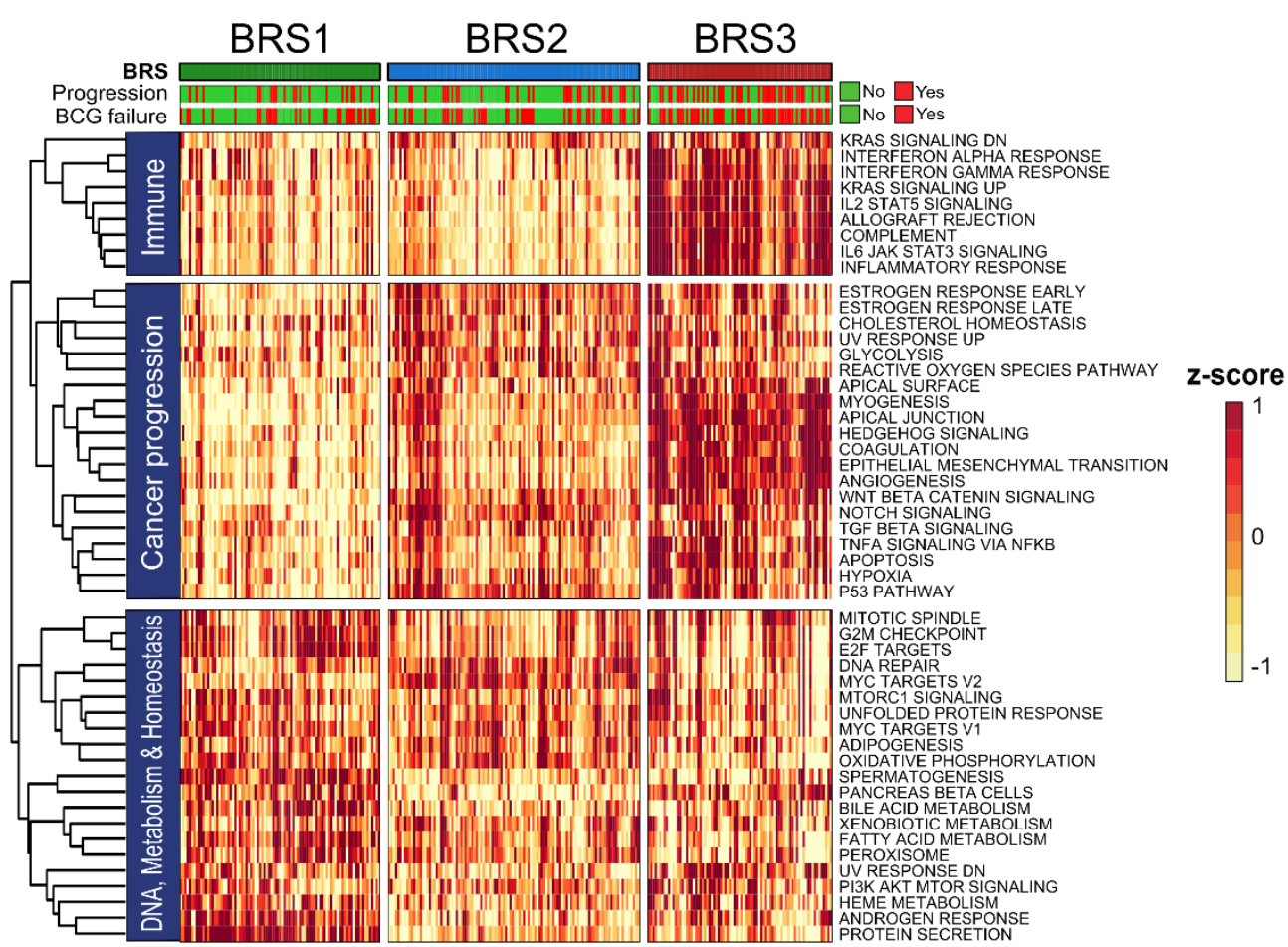

B

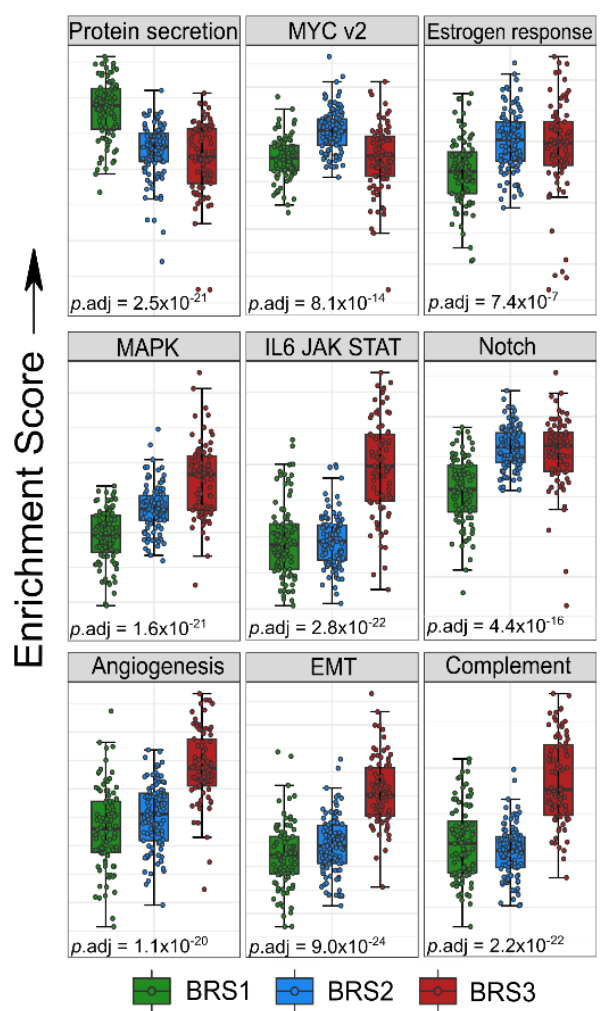

C

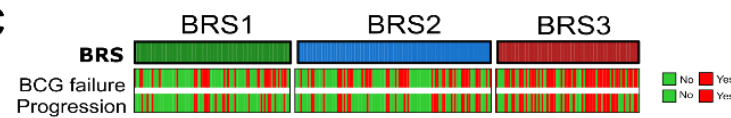

Fig. 2. Gene set enrichment analysis and regulon analysis grouped according to the BRS in Cohort A+B. A: Heatmap of all 50 GSEA hallmarks in $n=283$ pre-BCG, HR-NMIBC patients. Clustering on gene signatures (rows) indicate the existence of different molecular subtypes in HR-NMIBC. B: Boxplots of selected gene signatures in $n=283$ pre-BCG HR-NMIBC patients grouped according to BRS; $p$-values are Kruskall-Wallis tests. C: Heatmap of the top 200 most varying regulons using singlesample VIPER analysis on $n=283$ pre-BCG tumors grouped by BRS (columns). Hierarchical clustering between samples confirms three distinct molecular subtypes; key regulators for which small molecule inhibitors exist are highlighted. Abbreviations: BCG = Bacillus Calmette-Guérin; BRS = BCG Response subtypes; GSEA = gene set enrichment analysis; HR-NMIBC = high-risk nonmuscle invasive bladder cancer; VIPER = Virtual Inference of Protein Activity by Enriched Regulon Analysis. 
medRxiv preprint doi: https://doi.org/10.1101/2021.11.30.21266988; this version posted December 5, 2021. The copyright holder for this preprint (which was not certified by peer review) is the author/funder, who has granted medRxiv a license to display the preprint in

It is made available under a CC-BY-NC 4.0 International license.

DGE analysis showed that BRS1-2 tumors had overexpression of the luminal marker PPARG (Fig. S6A, Table S3). A typical luminal marker is FGFR3, but FGFR3 expression was high in BRS2 tumors only. Pathway analysis revealed BRS1 tumors had upregulated cell cycle and metabolic processes involved in mycobacterial (BCG) processing, such as enrichment of autophagy, ubiquitination and proteasome degradation and protein secretion (Fig. 2B, Table S4). These findings provide mechanistic insight into the more favorable outcome associated with BRS1 patients after BCG treatment. GSEA indicated that BRS2 was the least enriched for immune related pathways (Fig. 2A) [27]. MYC pathway activity (Fig. 2B), the absence of a carcinoma in situ (CIS) profile (Fig. 1C/S3), enriched luminal signatures (Fig. S6C) and a high proportion of pure urothelial cell carcinoma (Table 1) were associated with BRS2. Hence, BRS2 tumors align with features seen in papillary BC. Subtype-specific and potential druggable regulatory proteins are listed in Fig. $2 \mathrm{C}$. The activity of luminal regulators, FOXM1, FOXA1, GATA3 and ERBB3 was high in both BRS1 and BRS2 tumors, but not in BRS3 tumors. Consistent with luminal papillary MIBC, BRS2 tumors retained SHH activity (Fig. S6B) [18]. Taken together, characterization of BRS1 and BRS2 tumors shows these are molecularly distinct, but both share luminal features, which may explain the better outcomes after BCG.

\section{The tumor microenvironment of BRS3 displays immune suppressive features}

BCG immunotherapy is dependent on interactions with the tumor microenvironment (TME). As findings pointed towards high immunological activity in BRS3 with a poor outcome after BCG treatment, we analysed the TME using transcriptome deconvolution and spatial proteomics. First, we assessed the overall immune infiltration using the ESTIMATE algorithm and confirmed that BRS3 tumors had the highest immune and lowest tumor purity scores as compared to BRS1-2 tumors (Fig. 3A) [28]. To gain further insight into immune cell composition of BRSs, we applied the CIBERSORT immune deconvolution method, which allowed for between tumor and between immune cell population comparisons [29]. BRS3 showed the highest infiltration of $B$ cells, tumor-associated macrophages (TAMs) M1/M2, CD8+ $T$ cells and $T$ regs (Fig. 3B). Findings were verified using two additional independent algorithms (Table S5) [30, 31].

Previous in vivo studies demonstrated a critical role for CD8+ T cells in BCG-mediated antitumor immunity [32, 33]. Therefore, high infiltration of CD8+ T cells in treatment-naive BRS3 tumors seemed a paradoxical finding, as most patients with BRS3 did not respond to BCG treatment. Thus, we investigated if BRS3 tumors have high CD8+ T cells at the protein level. In Cohort A, all BCG responders that were BRS1 ( $n=27)$ were selected, and from all nonresponders, we selected BRS3 tumors $(n=25)$. The luminal FGFR3 expressing BRS2 subtype was excluded, as our expression data indicated that BRS2 tumors had the lowest expression of immune-related genes. Immunohistochemistry was successfully performed on 48 selected pre-BCG BRS1/3 tumors with a clinically approved antibody for CD8+ T cells. Consistent with RNA expression data, we detected more intratumoral CD8+ T cells in BRS3 vs. BRS1 tumors $(p=0.12$, Fig. $3 C$ ), but results were not statistically significant. The same tumors were also investigated by multiplex proteomics for CD4+, T regs, B cells and Macrophages (M1/M2) and Vimentin (VIM). Areas surrounding the macrodissected tumor punches used for RNA isolation were selected (Fig. 3D). We confirmed an increased number of tumor infiltrating immune cells (CD4+ $p=0.021]$, T regs, B cells and Macrophages) and a higher expression of intratumoral VIM $(p<0.001)$ in BRS3 on a protein level as compared to BRS1 using automated quantification on tumoral vs stromal tissue (Fig. 3E). Interestingly, in several patients with early progressive disease, high infiltration with Macrophages $M 2$ and $T$ regs was seen, suggesting that this might serve as marker for treatment failure in a subset of patients (Fig. 3F). Taken together, despite a clear trend towards higher CD8+ T cells and Macrophages on 
medRxiv preprint doi: https://doi.org/10.1101/2021.11.30.21266988; this version posted December 5, 2021. The copyright holder for this preprint (which was not certified by peer review) is the author/funder, who has granted medRxiv a license to display the preprint in

perpetuity.
It is made available under a CC-BY-NC 4.0 International license.

RNA-level, results were not significantly recapitulated at the protein level, possibly due to sample size. Nonetheless, BRS3 tumors were more infiltrated with T regs and B cells, both associated with immune suppression, and these findings have previously been linked to a poor clinical outcome after BCG [34, 35].

A

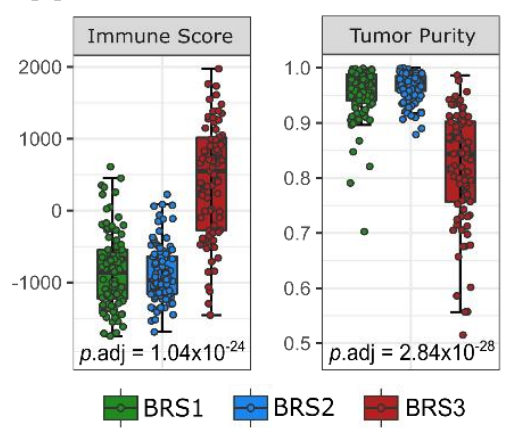

D
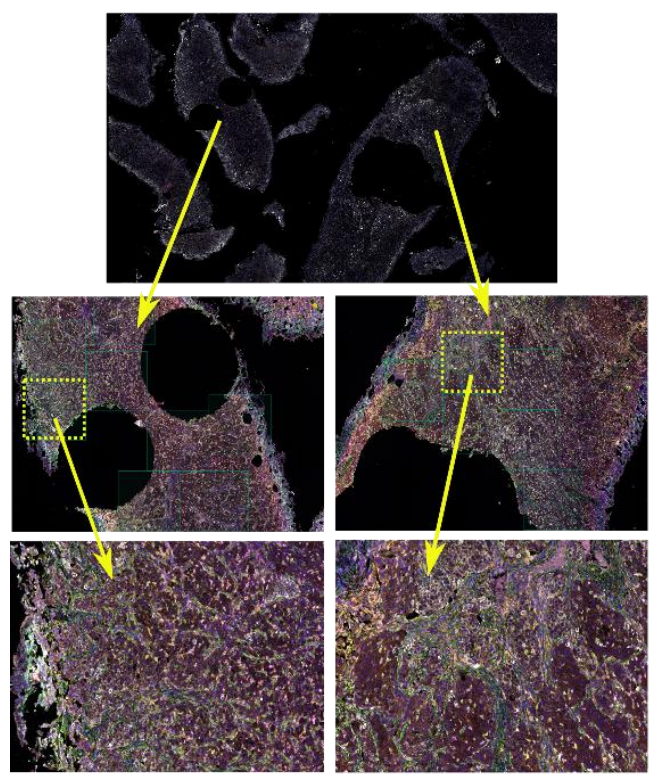

B

E
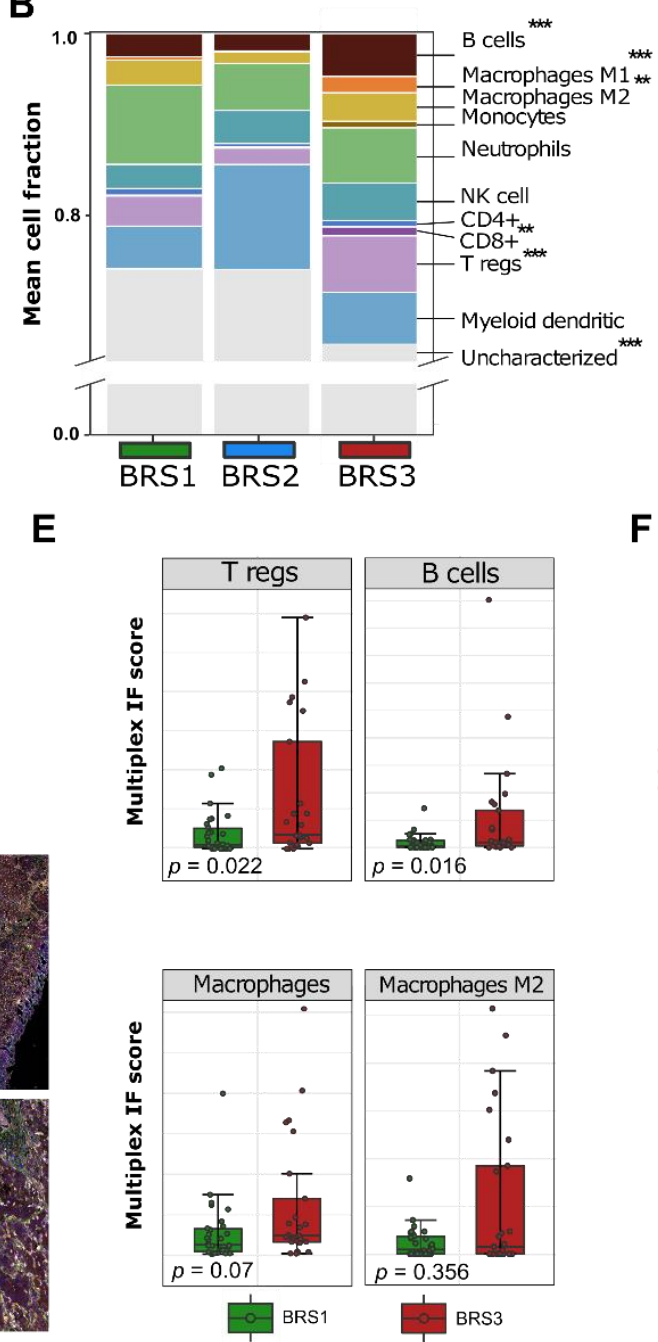

C

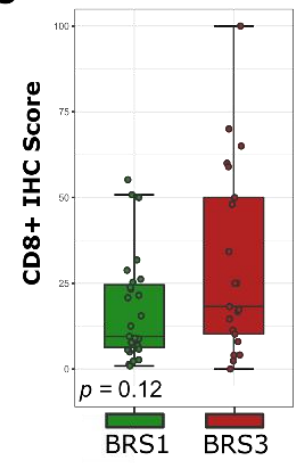

$\mathbf{F}$
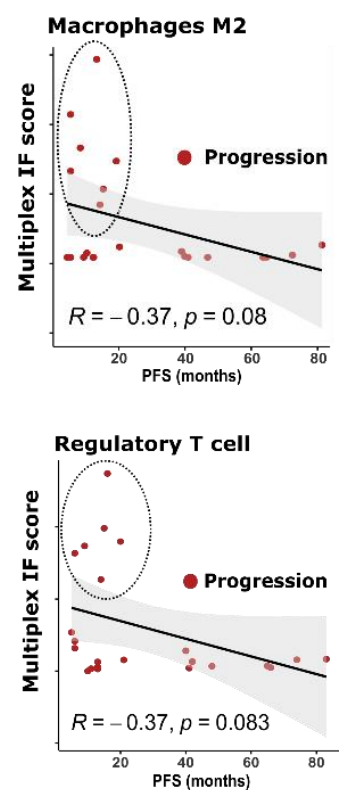

Fig 3. Immune deconvolution of pre-BCG tumors from Cohort $A+B$ and spatial proteomics of the tumor microenvironment grouped by BRS from Cohort A. A: Boxplots predicting tumor purity and immune infiltration in $n=283$ preBCG tumors grouped by BRS [28]; $p$-values are Kruskal-Wallis tests. B: Immune cell deconvolution from RNA-seq: a single column is the sum of ten immune cell subpopulations and non-characterized cells grouped by BRS; $p$-values are Wilcoxon tests for BRS1/2 vs BRS3; ${ }^{* *} p . \operatorname{adj}<10^{-3}$; ${ }^{* * *} p \cdot \operatorname{adj}<10^{-4}$. C: Immunohistochemistry of CD8+ cytotoxic T cell infiltration in $n=25$ BRS1 and $\mathrm{n}=27$ BRS3 tumors. BSR2 tumors were excluded, as data indicated very low immunological activity in these tumors. D: Selection of regions for spatial proteomics; on average 20 regions of pre-BCG BRS1/3 tumors surrounding the macrodissected areas used for RNA-sequencing were selected. Mean intratumoral protein expression was used for analyses. E: Boxplots of multiplex immunofluorescence (regulatory T cells, B cells, Macrophages and Macrophages M2) for $n=27$ BRS1 and $n=25$ BRS3 tumors. F: Scatterplot for immunofluorescence results for only patients with progression. Only few patients had tumors that were high in regulatory $T$ cells and macrophages $M 2$, yet all of these patients had early progressive disease ( $\leq 2$ year). Abbreviations: $B C G$ = Bacillus Calmette-Guérin; BRS = BCG response subtypes.

\section{BRS improves current clinical risk stratification of HR-NMIBC}

We investigated how the BRSs impact BCG response and clinical outcome in Cohort $A+B$. According to international recommendations, BCG response is defined as being free of highgrade $(\mathrm{HG})$ disease after 6 months of adequate BCG exposure [36]. Using this endpoint, a differential response to BCG treatment was observed between subtypes (BRS1 85\%, BRS2 $82 \%$, BRS3 68\%; $p=0.017$ ). In addition to PFS (Fig. 4A), patients with BRS3 tumors had a poorer HG recurrence-free survival (Fig. 4B). In multivariate analyses, BRS3 vs. BRS1/2 was an independent predictor of PFS (HR 2.7, p<0.001, Fig. 4C). 
medRxiv preprint doi: https://doi.org/10.1101/2021.11.30.21266988; this version posted December 5, 2021. The copyright holder for this preprint (which was not certified by peer review) is the author/funder, who has granted medRxiv a license to display the preprint in perpetuity.

It is made available under a CC-BY-NC 4.0 International license.

Next, we analyzed the added value of the BRS classifier to the clinicopathological risk stratification of HR-NMIBC recommended by the EAU guidelines [1]. This risk stratification is based on the presence of stage T1, grade 3 or high-grade, concurrent CIS, multifocality, large tumors $(\geq 3 \mathrm{~cm})$, aggressive forms of variant histology and lymphovascular invasion which are associated with a high risk (HR) or a very high risk of progression (HHR) [1]. As HHR patients have a higher risk of progression than HR patients, guidelines recommend consideration of an early RC (instead of BCG). In our study, HHR patients had a 2 -year PFS of $75 \%$ vs $85 \%$ for HR patients ( $p=0.01$, Fig. 4D). Combining the BRS with the EAU HR-NMIBC risk model improved risk stratification by identification of a subgroup of patients with the highest risk of progression (HHR3) (Fig. 4E). HHR3 patients had a 2-year PFS of only 54\%. Importantly, HHR1 vs HHR2 patients, normally also considered for early RC, now have a similar 2-year PFS as HR patients. Considering the strong findings on BRS combined with clinicopathological features to predict outcome, we developed a preliminary nomogram for the research community to estimate the risk of progression, which should be validated prospectively (Fig. S7A). Finally, we assessed whether previously reported RNA-subtypes were able to predict response to BCG treatment in our total Cohort A+B. None of the published MIBC or NMIBC subtypes could identify a clinically relevant subset of patients with the highest risk of progression (Fig. S8A-G).

A PFS

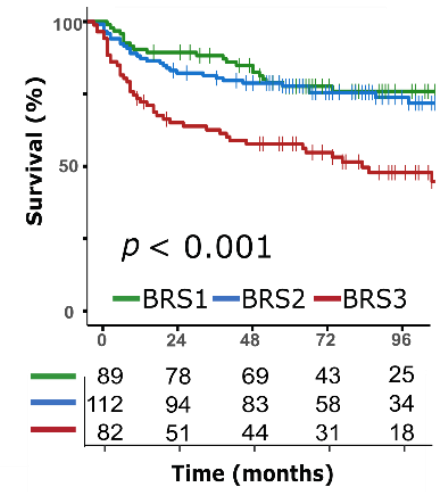

D PFS: EAU stratification

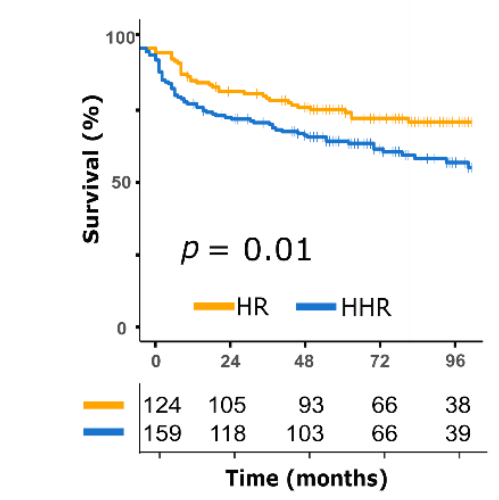

B RFS

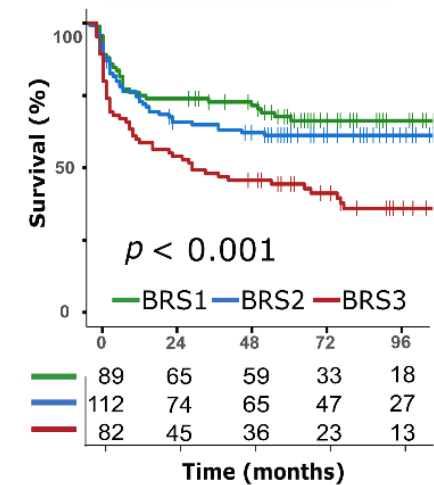

E

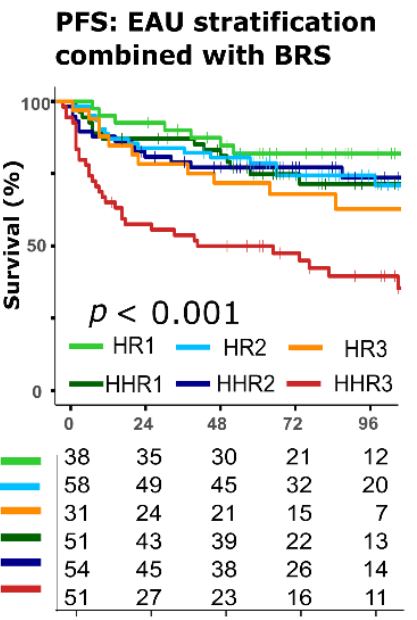

C

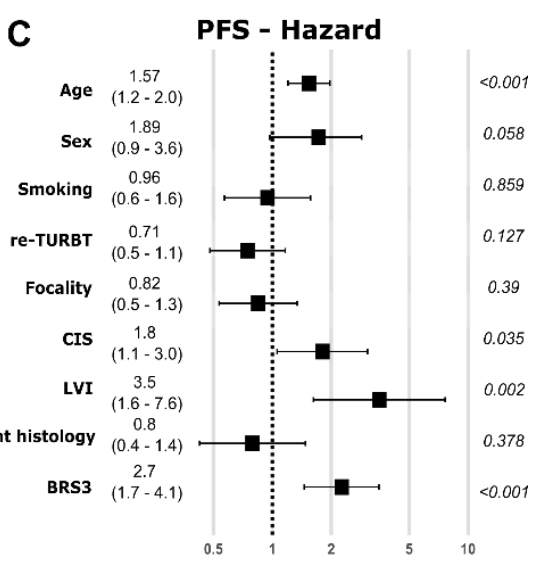

$\mathbf{F}$

OncoSignal performance

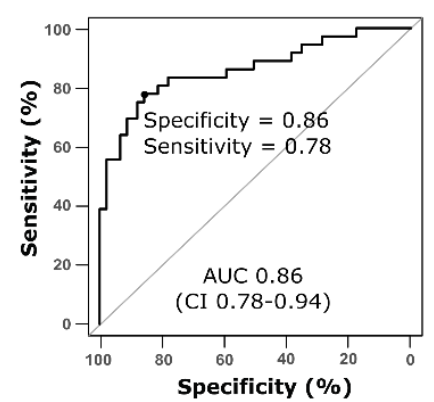

Time (months)

Fig. 4. Kaplan-Meier estimates of survival according to the $B R S$ in $n=283$ pre-BCG HR-NMIBC patients (Cohort A+B) and assay performance to predict BRS3 in Cohort A. A: Progression-free survival (PFS) stratified according to BRS. B: Recurrence-free survival (RFS) for high-grade tumor recurrences stratified according to BRS. C: Forest plot of multivariable Cox regression analysis; BRS3 vs BRS1 + BRS2. D: PFS stratified for the current EAU guideline recommendations (high-risk [HR] patients vs subgroup of very high-risk [HHR] patients). E: PFS stratified for current EAU risk-stratification and the BRSs. F: Subtype prediction for BRS3 vs BRS1/2 based on the assay results in Cohort A. Figure depicts the ROC with the area under the curve based on a logistic regression model, with corresponding test sensitivity and specificity reported at a threshold of 0.385 . Abbreviations: $B C G$ = Bacillus Calmette-Guérin; $B R S=B C G$ response subtypes; $E A U$ = European Association of Urology; HRNMIBC $=$ high-risk non-muscle invasive bladder cancer; Progression free survival (PFS). 
medRxiv preprint doi: https://doi.org/10.1101/2021.11.30.21266988; this version posted December 5, 2021. The copyright holder for this preprint (which was not certified by peer review) is the author/funder, who has granted medRxiv a license to display the preprint in

It is made available under a CC-BY-NC 4.0 International license.

BRS3 patients can be identified with a commercially available test

278 To investigate the clinical utility of the BRS, we assessed whether a commercially approved assay (OncoSignal®) was able to identify BRS3 versus BRS1-2 tumors. The assay is qPCRbased and measures seven signal transduction pathways (details in methods) [37]. The same RNA used for transcriptomic sequencing of Cohort $A$ was selected for OncoSignal® analysis. The assay was able to distinguish BRS3 from BRS1/2 tumors with BRS3 having high signal transduction activity of MAPK, ER, and Notch pathways (Fig. S7B). Slight differences between BRS3 and BRS1-2 were found based on Hedgehog, PI3K and TGF $\beta$ pathways. From a clinical perspective, it is important to distinguish aggressive BRS3 tumors from both BRS1/2 tumors, as BRS3 tumors might benefit from a different therapeutic strategy than standard-of-care. Thus, based on the pathway activity scores, we developed a logistic regression model to predict if a tumor was BRS3. The model resulted in strong overall performance (AUC 0.86), with optimized thresholds resulting in a true positive rate of $78 \%$ and true negative rate of $86 \%$ (Fig. 4F). Although findings need validation in an independent cohort, we have established for the first time that a commercially available assay can be used to identify a clinically relevant aggressive type of HR-NMIBC.

\section{Post-BCG tumor recurrences are enriched for BRS3}

To gain further insight into molecular changes that occur after BCG treatment failure, we applied the BRS classifier to 44 post-BCG tumors (34 pre/post-treatment matched tumors). Strikingly, BRS3 predicted tumors were enriched in post-BCG 28/44 (64\%) recurrences vs pre-BCG tumors $82 / 283$ (28\%) (Fig. 5A). From the 34 matched tumors, 26/34 patients had BRS1-2 tumors pre-BCG of which 14/26 tumors switched to BRS3 post-BCG.

Overexpressed genes in post-BCG samples can indicate mechanisms involved in BCG treatment failure and might therefore provide candidate target genes for development of novel treatments. Paired DGE analysis revealed that in post-BCG tumors, CYP1A1 and CYP1B1 were highly overexpressed, both key genes involved in phase-1 drug metabolism (modification), as well as genes essential for attachment of BCG to urothelial cells (FN1, FNDC1, ITGA5). These results in tumors that do not respond to treatment, indicate that overexpression could be a consequence of ineffective mycobacterial antigen exposure to urothelium. EMT related genes (ZEBS, TGF $1 / 3$ ), growth factors (FGF2, FGF7, HGF) and genes associated with basal-like disease and cancer progression (CD44, KRT6/16, LGALS7) were overexpressed (Fig. 5B) [38-40]. Collagen receptor DDR2 and EMC remodeling genes (MMPS, ADAMTSs, VCAN, FAP) were also highly overexpressed after treatment. Although these genes are involved in wound healing and tumor scarring, extensive preclinical work has shown that they promote bladder cancer metastases and are predictive of a poor outcome [41-43]. Additionally, post-BCG tumors showed increased expression of SFRPs - WNT antagonists - which is consistent with the WNT pathway activity found in pre-BCG BRS3 tumors and might indicate WNT signaling involvement in BCG resistant tumors [44]. Overall, of the multiple genes differentially overexpressed in tumors displaying the pre-BCG BRS3 gene signature, most were overexpressed in tumors that failed treatment and described in the literature to be associated with cancer progression (Table S6). Many of these genes can be targeted by available small molecules, providing an excellent starting point for development of novel treatments in these BCG-resistant patients [25].

Next, we investigated consistently expressed gene fusions, important regulatory networks, pathways and non-synonymous SNVs to investigate which potentially actionable mechanisms underlie recurring disease post-BCG. We identified gene fusions that were present before and after treatment within the same patient. Although infrequent, druggable gene fusions such as 
medRxiv preprint doi: https://doi.org/10.1101/2021.11.30.21266988; this version posted December 5, 2021. The copyright holder for this preprint (which was not certified by peer review) is the author/funder, who has granted medRxiv a license to display the preprint in It is made available under a CC-BY-NC 4.0 International license .

FGFR3--TACC3 fusions were detected in three patients (Fig. S9A, Table S7). Transcriptional regulators that were enriched in post-BCG tumors include DDR2, TGF $\beta s, A E B P 1$, glucocorticoid receptor NR3C1 and Fibroblast growth factor FGF7 (Fig. 5C, Table S6). By performing a within-patient pathway analysis, we noted enrichment of EMT, complement, IL6JAK-STAT3 and angiogenesis in post-BCG recurring tumors (Fig. 5D; Table S6), supporting the hypothesis that recurrences have a more aggressive biology. Signatures that contributed to the pre-BCG BRS3 were also the dominant signatures present in recurring tumors (Fig. S9B, Table S6). Variant calling identified significant mutational differences between pre- and post-BCG tumors. Interestingly, a dozen of these genes belonged to EMC organization, which is interesting as ECM signatures were overexpressed in treatment failures as well (Fig. S9C; Table S6). To summarize, post-BCG tumors displayed enrichment of pathways that are involved in cancer progression. Additionally, several promising actionable targets in post-BCG recurrences were detected.

Finally, we investigated the TME of post-BCG recurrences. Immune deconvolution on matched samples showed more T regs, Macrophages and B cells in post-BCG tumors (Fig. 5E). Intratumoral multiplex spatial proteomics of $n=85$ samples showed an increased presence of immune subpopulations in post-BCG BRS3 (Fig. 5F). From the post-BCG recurrences, only BRS3 tumors showed a trend towards increased numbers of regulatory $\mathrm{T}$ cells and Macrophages (M2) as compared to BRS1-2 tumors (Fig. 5G). Protein analysis pointed towards a phenotype that is associated with immune suppression in tumors that fail BCG treatment.

Altogether, these data strongly support the hypothesis that BRS3 tumors have a clinically and biologically aggressive phenotype. In addition, paired analyses of tumors that did not respond to BCG provide targetable gene candidates for preclinical research into alternative treatments for BCG non-responsive tumors. 
medRxiv preprint doi: https://doi.org/10.1101/2021.11.30.21266988; this version posted December 5, 2021. The copyright holder for this preprint (which was not certified by peer review) is the author/funder, who has granted medRxiv a license to display the preprint in

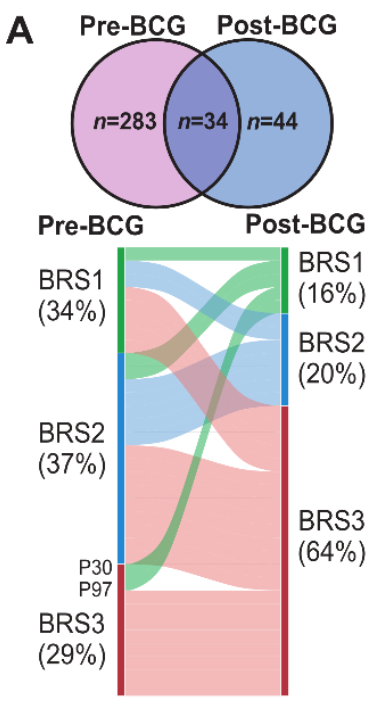

C

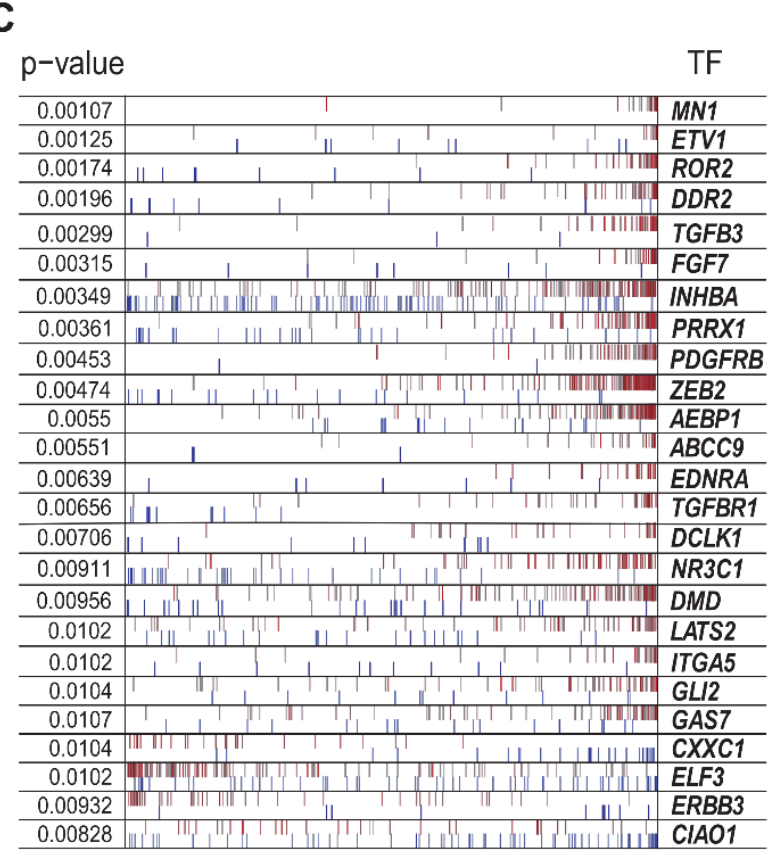

$E_{0}$
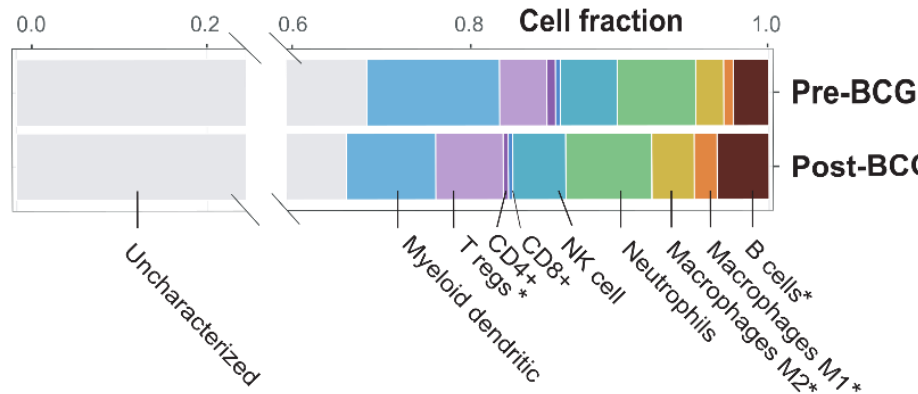

IIIII | || || || | || | || $\square$ Pre-BCG $\square$ Post-BCG

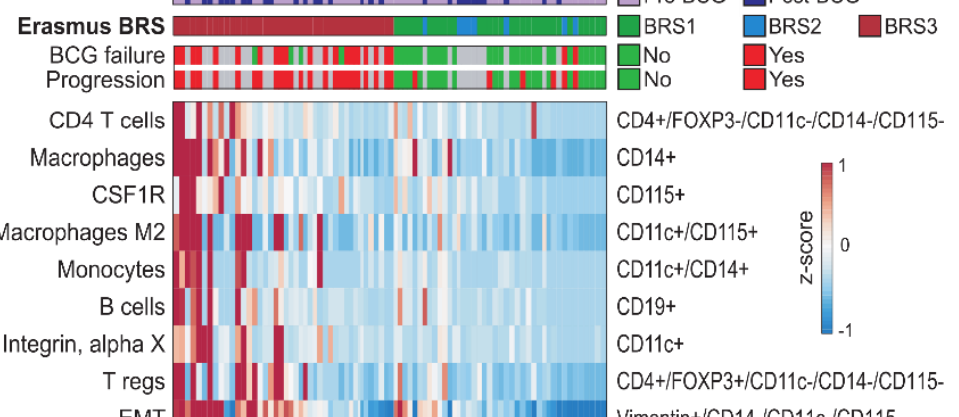
EMT
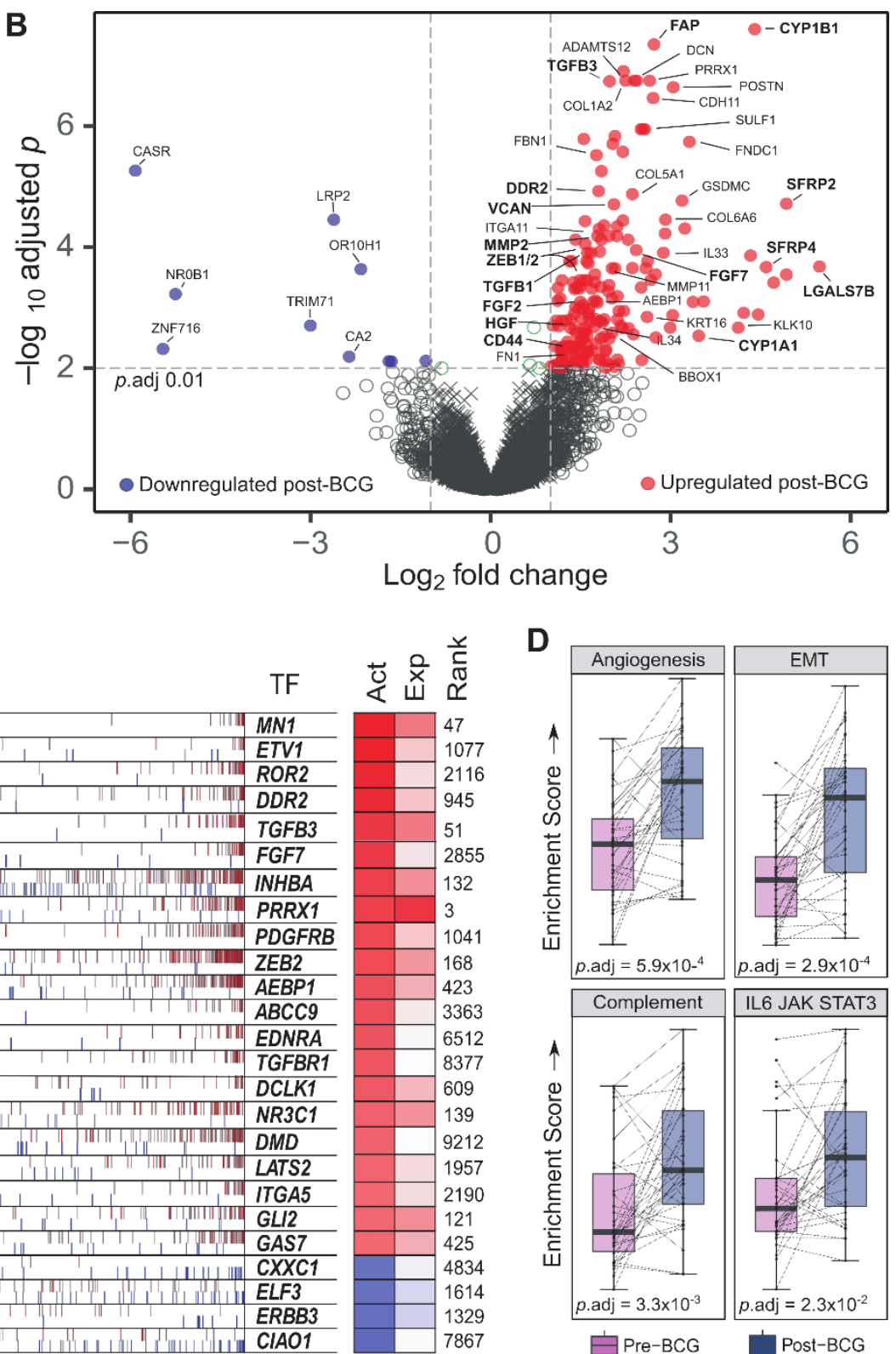

D

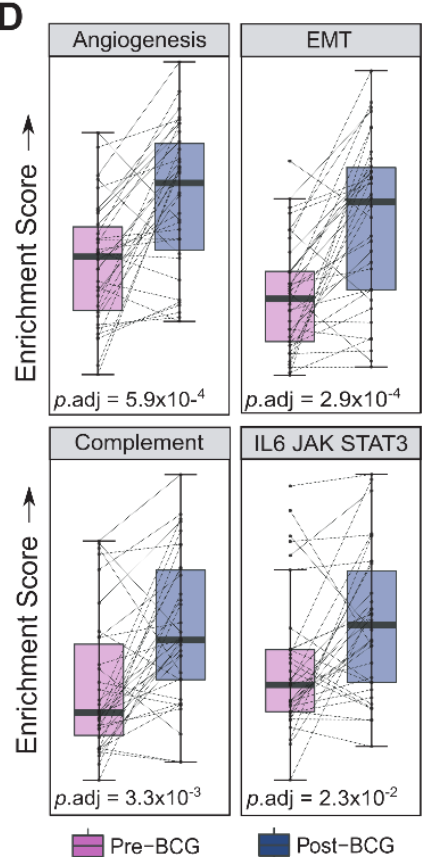

G

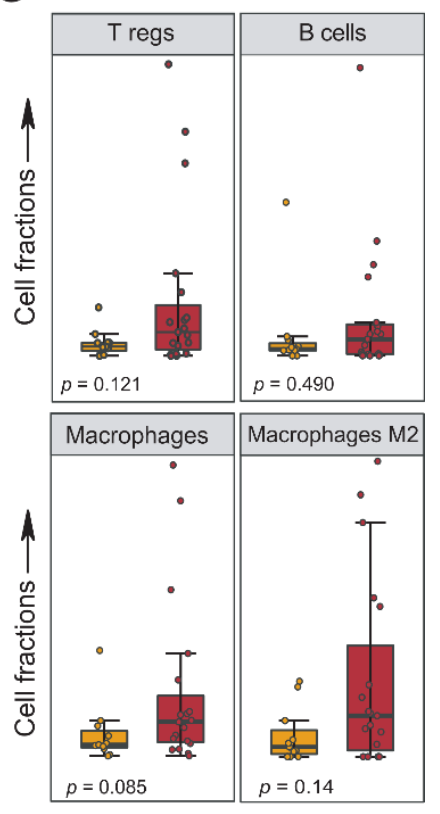

E $\mathrm{BRS} 1 / 2$ 투 BRS3 
medRxiv preprint doi: https://doi.org/10.1101/2021.11.30.21266988; this version posted December 5, 2021. The copyright holder for this preprint (which was not certified by peer review) is the author/funder, who has granted medRxiv a license to display the preprint in

It is made available under a CC-BY-NC 4.0 International license .

Fig. 5. Pre- vs post-BCG transcriptomic and spatial proteomic comparisons. A: Frequency of BRS in pre-BGC vs post-BCG tumors in Cohort $A+B$. Alluvial plot details 34 patients with matched pre- and post-BCG tumor samples. B: Volcano plot of differentially expressed mRNAs in matched post-BCG and pre-BCG tumors from $n=34$ patients. C: Top regulons with small molecule inhibitors that are up- or down-regulated in pre-BCG tumors and post-BCG tumors depicted. In red: regulators enriched in post-BCG recurrences. In blue: regulators enriched in pre-BCG tumors. D: Selected gene set enrichment hallmarks comparing $n=34$ paired pre- and post-BCG tumors samples. Dashed lines represent pathway activity scores between paired samples of a single patient; $p$-values are paired Wilcoxon tests. E: Immune cell deconvolution based on RNA-seq: a single column is the sum of ten different immune cell populations and non-characterized cells found in the tumor microenvironment grouped by pre-BCG tumors or post-BCG recurrences; $p$-values are Wilxocon tests; ${ }^{*} p$.adj<0.05. F: Heatmap with spatial proteomics grouped by subtype and sorted by $z$-score. Results indicate an increased presence of tumor infiltrating immune cells in BRS3 vs BRS1/2 tumors and post-BCG vs pre-BCG tumors. G: Proteomic results of $n=30$ post-BCG recurrences grouped by post-BCG BRS. BRS3 tumors had a non-significant increased number regulatory $T$ cells and Macrophages (M2). Abbreviations: $B C G=B a c i l l u s$ Calmette-Guérin; BRS = BCG response subtypes. 
medRxiv preprint doi: https://doi.org/10.1101/2021.11.30.21266988; this version posted December 5, 2021. The copyright holder for this preprint (which was not certified by peer review) is the author/funder, who has granted medRxiv a license to display the preprint in

It is made available under a CC-BY-NC 4.0 International license .

We analyzed the transcriptomes of HR-NMIBC patients to characterize molecular features associated with response to BCG. This is the largest study to date in BCG-treated HR-NMIBC patients that establishes the existence of molecular subtypes predictive of outcome after BCG. The robustness of the BRS classifier was validated in a second profiled HR-NMIBC patient cohort. We identify BRS3 as a clinically relevant subgroup of patients, who have enrichment of EMT activation markers, a basal and immunosuppressive phenotype, overexpression of immune checkpoint genes and a poor progression-free survival as compared to BRS1 and BRS2 patients. Addition of BRS to guideline-based patient risk groups improved stratification of patients with the highest risk of progressive disease. Current guideline recommendation on disease management of HR-NMIBC patients is to consider an early RC for tumors with veryhigh risk clinicopathological criteria. Molecular subtyping in very-high risk BRS1 and BRS2 patients have a significantly lower risk of progressive disease, which creates the possibility for these patients to preserve their bladder. In contrast, the addition of BRS3 to the very high-risk group showed an even poorer PFS, which suggests that these patients should strongly be considered for early $\mathrm{RC}$.

BCG treatment failure in $30-50 \%$ of patients is a major risk factor for progressive disease and death from BC. Thus, much effort has been made to identify patients that do not benefit from treatment and to search for treatment alternatives to radical surgery. Previous RNA-based molecular subtyping studies were not associated with clinical outcome after BCG treatment, possibly because these studies lacked sufficient numbers of patients or were difficult to interpret in the clinic due to the high number of subtypes [14]. UROMOL21 did identify three T1HG subtypes, but these subtypes were not able to predict failure of BCG treatment [13]. The T1BC subtyper was built for recurring disease and developed in a population with a limited number of patients who developed progression [17].

Previous work showed that the presence of tumor associated macrophages and FOXP3positive T regs in the TME are associated with worse outcome in BCG-treated BC [45]. Kates et al. found that BC progression occurred in BCG treated immunocompetent rats with an increased presence of $F O X P 3$-positive $T$ regs and rats having a decreased adaptive immunity [34]. BRS3 tumors also showed signs of CD8+ $T$ cell infiltration, Th1 polarization and interferon- $y$ pathway activity, vital for anti-tumor immunity and BCG effectiveness [46, 47]. This is a seemingly paradoxical finding as BRS3 tumors have the worst clinical outcome, but strong Th1 predisposition should be counterbalanced to avoid auto-immunity, which may explain the T regs, B cells and Macrophages in BRS3 tumors [48]. The IL2-STAT5 pathway was enriched in BRS3 tumors. Measurement of urinary IL-2 during and after BCG treatment has been proposed as a marker of response to BCG $[49,50]$. However, IL-2 also plays an important role in T reg development via STAT5 [51]. Because of the high CD8+ T cell activity in BRS3 tumors and the non-response to BCG immunotherapy, results might be suggestive of $T$ cell exhaustion in BRS3 tumors. Previous work indicates that $T$ cell exhaustion may lead to an ineffective cascade of additional anti-tumor immunity, which might play a role in diminished therapeutic success of BCG in BRS3 tumors [52, 53].

A strong aspect of this study is the availability of matching pre- and post-BCG treatment samples, which allows for the unique investigation of overexpressed genes in BCG treatment failures. For instance, previous work showed that TGF- $\beta$ attenuates anti-PD-L1 therapy outcomes by exclusion of cytotoxic T cells from the TME [54]. Here, high expression of TGF- 
medRxiv preprint doi: https://doi.org/10.1101/2021.11.30.21266988; this version posted December 5, 2021. The copyright holder for this preprint (which was not certified by peer review) is the author/funder, who has granted medRxiv a license to display the preprint in

It is made available under a CC-BY-NC 4.0 International license .

410 to overcome BCG-resistance and should be investigated as a druggable target. 411 Overexpression of checkpoint genes in BRS3 tumors (PD-(L)1, CTLA-4, etc.) in our study 412 provides a rationale for the use of immune checkpoint inhibition in BCG-unresponsive patients, 413 as observed in the Keynote-057 clinical trial where patients had a durable response to anti414 PD-1 [55]. Recently, anti-PD-1 combined with anti-CTLA-4 showed excellent response rates 415 as neoadjuvant therapy in MIBC, and the data indicates this strategy has potential in BCG416 unresponsive disease as well [56]. Lastly, in vivo studies showed positive synergistic effects 417 on tumor load and increased CD8+ T cell influx when dasatinib (anti-DDR2) was combined 418 PD-L1 blockade [57]. In addition to RNA overexpression of checkpoint proteins in BRS3, we 419 demonstrate an increased expression of DDR2 in post-BCG tumors, thus supporting the 420 potential of anti-PD-L1 combination treatment with anti-DDR2. The latter mechanism is in part 421 due to M2 macrophages via CCL2, in which CCL2 inhibition could improve checkpoint therapy $422[57,58]$.

423 BRS1 tumors had the most favorable PFS and showed molecular similarities to the genomic subtype, GS2, previously identified by Hurst et al. in stage Ta/low-grade BC [12]. BRS1 tumors had increased expression of genes related to intracellular protein trafficking and antigen presentation, which is vital for mycobacterial processing, and $\mathrm{MHC1}$-mediated cytotoxic $\mathrm{T}$ cell killing of cancer cells [59-63]. Enhanced autophagy has been found to be important in processing of BCG and improved antigen presentation in vivo $[64,65]$. SNPs in ATG5 and ATG2B negatively influence trained immunity after restimulation with BCG and inhibition of autophagy directly attenuated bacterial processing and antigen presentation [66]. These results led us to hypothesize that enhanced autophagy during BCG treatment will improve the immune response.

BRS2 tumors were luminal, with high FGFR3 expression, activation of MYC, but substantial within-subtype heterogeneity. Luminal heterogeneity is a consistent finding in BC and complicates clinical implementation of subtyping [67]. The relationship of MYC to FGFR3 activity was elucidated in vitro, in which Mahe et al. discovered that FGFR3 expression led to downstream MYC accumulation and increased FGFR3 activity in a positive feedback loop [68]. Recently, anti-FGFR treatment in metastatic BC was shown effective with low toxicity rates [69]. Therapeutic inhibition of FGFR is an option that has potential therapeutic translation in BRS2 tumors given the high prevalence of FGFR alterations in NMIBC and high FGFR3 activity in BRS2 tumors. Of interest was N2RF6 regulon activity in BRS2 tumors. Recently, it was shown that loss of N2RF6 in a CRISPR/Cas9 mouse model leads to hyper-responsive $T$ cells and enhanced responses to PD-L1 inhibition [70, 71]. It would stand to reason that blocking N2RF6 could sensitize BRS2 tumors to immune-checkpoint inhibition.

Although next-generation sequencing data is more easily accessible, molecular subtyping based on transcriptomics remains time-consuming, expensive and requires dedicated personnel. To pave the way for clinical translation of our findings, we used a commercially approved qPCR-based assay and show that this test is able to accurately identify BRS3 HRNMIBC patients. As a next step, a non-randomized phase 2 study is needed to assess the predictive value of BSR3 in a prospective manner. To this end, a comparison between the BRS transcriptomic classifier and the commercial assay is required to test whether OncoSignal can be widely used as a means to stratify HR-NMIBC patients. Alternatives to BCG treatment based on assay results can also be investigated. Clinical trials targeting signal transduction pathways, such as MAPK and Notch are ongoing, and based on our findings, these pathways are candidates for further investigation in BRS3 tumors [72, 73]. Finally, it would be interesting to enhance assay stratification by inclusion of immunological pathways such as JAK-STAT, 
medRxiv preprint doi: https://doi.org/10.1101/2021.11.30.21266988; this version posted December 5, 2021. The copyright holder for this preprint (which was not certified by peer review) is the author/funder, who has granted medRxiv a license to display the preprint in It is made available under a CC-BY-NC 4.0 International license.

457 which was highly upregulated in (post-BCG) BRS3 patients and is also considered as target 458 for pathway-directed precision medicine [74].

459 This study is not without limitations. First, tumors from BCG non-responders were 460 overrepresented as compared to a real-world situation [75]. For the discovery cohort, we 461 specifically selected true BCG responders and BCG non-responders, because the objective 462 was to find molecular characteristics associated with response to BCG. Second, the 463 OncoSignal assay was run on the same RNA as we performed RNA-sequencing on. While 464 comparison between these assays is a necessary first step, independent validation using RNA 465 from an independent cohort must be done. Third, future studies should address the issue of 466 RNA-based spatial heterogeneity, as false positive and false negative subtypes might be a 467 result of sample collection bias or inherent BC subtype heterogeneity [76, 77]. Assessment of 468 histological and molecular heterogeneity will likely help to explain BCG-resistance due to 469 selection pressure, which may have prognostic and therapeutic implications [78, 79]. We found 470 that the proportion of BSR3 increased in post-BCG recurrences. Therefore, we speculate that 471 progression from BRS1/2 to BRS3 after treatment failure is due to tumor plasticity and clonal 472 expansion of aggressive tumor cells.

473 To conclude, our findings showed the prognostic relevance of molecular subtypes in HR474 NMIBC patients. We showed that subtyping can improve the clinical risk stratification and we 475 translate our findings via OncoSignal ${ }^{\circledR}$, a consumer-ready pathway activity diagnostic test. In 476 addition, the data presented provided unique pre- and post-treatment evidence for 477 development of novel targeted therapies, targeting tumors that fail BCG treatment. 478 Identification of BRS3 tumors may be a critical step for implementation of more aggressive 479 therapeutic regimens such as an early $\mathrm{RC}$ or recruitment into clinical trials. 
medRxiv preprint doi: https://doi.org/10.1101/2021.11.30.21266988; this version posted December 5, 2021. The copyright holder for this preprint (which was not certified by peer review) is the author/funder, who has granted medRxiv a license to display the preprint in

It is made available under a CC-BY-NC 4.0 International license .

\section{Materials and Methods}

Patients \& Pathology

Tumor samples from primary HR-NMIBC patients who had received $\geq 5 / 6$ BCG-induction instillations between 2000-2018 at four different Dutch hospitals (Erasmus University Medical Center Rotterdam, Franciscus Gasthuis and Vlietland Rotterdam, Amphia Breda and Reinier de Graaf Gasthuis, Delft) and one Norwegian hospital (Stavanger University Hospital) were compiled. IRB approval was obtained from the Erasmus MC Medical Research Committee (MEC-2018-1097). The regimen of BCG instillations was according to the Southwest Oncology Group (SWOG) protocol; clinical follow-up was according to the European Association of Urology (EAU) guidelines [1]. Formalin fixed paraffin-embedded (FFPE) material, including TURBTs, re-TURBTs, tumor recurrences, random biopsies, radical cystectomies (RC), pelvic lymph node dissections (PLND) and distant metastases were reviewed by an expert uropathologist (R.F.H.) in accordance with WHO standards for classification of the urinary system and was previously published [3, 80]. Patients were classified as high risk or as very high risk subgroup according to the EAU guidelines on NMIBC. Very high risk criteria included: multiple and/or large tumors $(\geq 3 \mathrm{~cm})$, and/or concomitant CIS, and/or lymphovascular invasion (LVI) and/or certain aggressive forms of variant histology (e.g. micropapillary, sarcamatoid etc.) [1].

\section{Definitions \& Statistics}

Cohort A consisted of $n=63$ BCG responders and $n=69$ BCG non-responders. Response to BCG was defined as the absence of a high-grade recurrence following at least 5/6 BCG induction instillations and $\geq 9$ BCG maintenance instillations (i.e. 1-year schedule with at least 3 cycles of BCG maintenance). Cohort A had a median of 18 instillations. Non-response to BCG was defined as the development of one of the following: i) biopsy-proven muscleinvasive bladder cancer, ii) persistent T1HG NMIBC after BCG induction, iii) high-grade NMIBC after adequate BCG therapy, which was defined as $\geq 5 / 6$ BCG induction instillations plus $\geq 2 / 3$ BCG maintenance instillations. Only patients were included in whom pathology review showed invasion of high-grade $(\mathrm{HG})$ urothelial cancer cells into the lamina propria (T1HG NMIBC) with absence of cancer cells in the detrusor muscle of the primary TURBT or re-TURBT. BCG-naive tumor samples were selected for whole transcriptome analysis from both BCG responders and non-responders, and from the latter group, we additionally included samples that were the first $H G$ tumor recurrences during BCG therapy, which could be TaT1HG or T2. For Cohort B, additional patients with HR-NMIBC were included. Cohort B resembled Cohort $A$, with the aim to have a similar number of tumors that responded to $B C G$ $(n=88)$ and that did not respond to BCG $(n=63)$. To increase the number patients in Cohort $B$, we also included patients with Ta tumors. In Cohort $B$, patients received $\geq 5 / 6$ BCG induction instillations, with a median of 13 instillations.

The primary end point was the progression-free survival (PFS), defined as the time from HRNMIBC diagnosis until development of MIBC, lymph node (LN) or distant metastatic $\left(M_{+}\right)$ disease. Secondary end point was the high-grade recurrence-free survival (HG-RFS), defined as the time from HR-NMIBC diagnosis until a biopsy-proven HG recurrence had occured. Disease-specific survival (DSS) was defined as time from HR-NMIBC diagnosis until death of BC. Patients who were lost to follow-up were censored at the last date of follow-up or death. For the between subtype comparisons, a Fisher's Exact Test for categorical data or a KruskallWallis test for non-parametric continuous data was used. Kaplan-Meier (KM) estimation coupled with the log-rank statistical test was used to model survival over time with KM plots truncated at 8 years. A multivariable Cox-proportional hazard model was generated to determine whether BRS was associated with PFS. Model variables included age, sex, re- 
medRxiv preprint doi: https://doi.org/10.1101/2021.11.30.21266988; this version posted December 5, 2021. The copyright holder for this preprint (which was not certified by peer review) is the author/funder, who has granted medRxiv a license to display the preprint in

It is made available under a CC-BY-NC 4.0 International license .

TURBT, tumor focality, CIS, LVI and BRSs (BRS1 + BRS2 vs BRS3). Tumor size was excluded due to missing variables. To prevent understaging of primary $\mathrm{T} 1$ disease and to exclude bias from absence of a re-TURBT, additional analyses of Cohort A was performed on patients only with a re-TURBT available. For all between subtype and survival analyses, results were determined to be significant at $p<0.05$.

\section{Clustering analysis pipeline and molecular clustering}

Details on whole-transcriptome sequencing and tissue selection are in the supplementary materials and methods. The R package cluster was used to split (3:1) Cohort A based on two 2 variables (BCG-failure [yes/no] and Progression [yes/no]) [81]. The training cohort $(n=99)$ was filtered for protein coding transcripts (R package AnnotationDbi) [82]. We also removed all immune related genes (union of the signature genes from quanTIseq, EPIC and CIBERSORT algorithms, see following section) from our dataset [29-31]. This strategy prevents predominant clustering on immune related genes and enables between cluster comparisons using RNA-seq based immune cell deconvolution, which makes use of the filtered signature genes. Then, we performed unsupervised clustering ( $R$ package ConsensusClusterPlus) with top variant genes (500-6000) with steps of 250 genes ranked based off of the calculated row variance [83]. Arguments for ConsensusClusterPlus included: partitioning around medoids (PAM), Pearson correlations and iterating 2500 times with $95 \%$ samples. We determined that clustering with the 2000 top variant mRNAs resulted in the most robust sample allocation for three clusters (Fig. S1B) as determined by intercluster variation defined by the CDF plot, consensus matrix, and leading to clear differences in PFS (Fig. S1C). After analyzing survival and interpretation of GSEA results between clusters, we deemed three gene clusters as clinically informative and useful. Clustering labels from the training cohort was used to produce a multiclass predictive gene signature with the shrunken nearest centroid method (R package pamr) [84]. The resulting pamr object was able to predict three classes in the testing cohort $(n=33)$. Based on estimated survival (Fig. S1D) and overlapping GSEA hallmarks between identical subtypes from both training and testing cohorts (Fig. S1E), we confirmed the discovery of three distinct molecular subtypes in Cohort A.

The next step in establishing the algorithm parameters was clustering of all pre-BCG Cohort A patients using the established input parameters. To this end, Cohort $B$ was quantile normalized and matched to Cohort $A$ (the top 2000 most varying genes between samples). Results of ConsensusClusterPlus were used to investigate three, four and five gene clusters (Fig. S1F). We again determined that the 3-cluster solution was again the best fit for the data based on intercluster variation through internal validation, differences in GSEA pathway analyses between clusters and survival analysis. We generated a pamr-based nearestcentroid gene classifier based on the PAM model from Cohort A using an optimal threshold of 0.1652 . This threshold was chosen as this produced the least misclassifications. We locked our model and set out to validate the BRS in Cohort B.

\section{Subtype validation and calculating molecular signatures}

The BRS classifier was used to predict the BRSs for Cohort B. Similarly, the BRS classifier was also applied to the BCG samples from UROMOL21, to the T1BC dataset (GSE154261) and the TGCA dataset [13]. The TCGA BLCA dataset was downloaded using the Genomic Data Commons (GDC) portal (via https://portal.gdc.cancer.gov/projects/TCGA-BLCA). For both datasets, raw counts were VST normalized using DESeq2 and then used for downstream analyses. Using the consensusMIBC $R$ package, we generated all MIBC subtypes from our expression matrices [85]. A 68-gene CIS signature score was also built based on a previously reported study from Dyrskjot et al. [86]. The luminal BC signature (Fig S6C) included the following genes: FGFR3, PPARG, FOXA1, GATA3, ERBB2 ERBB3, DDR1, UPK1A, UPK2, 
medRxiv preprint doi: https://doi.org/10.1101/2021.11.30.21266988; this version posted December 5, 2021. The copyright holder for this preprint (which was not certified by peer review) is the author/funder, who has granted medRxiv a license to display the preprint in

It is made available under a CC-BY-NC 4.0 International license .

UPK3A, UPK3B, KRT18, KRT19, KRT20, CDH1, FABP4, CD24, XBP1 and CYP2J2. For T1 classification, the classifyT1BC R package was used [17]. Results are depicted with KaplanMeier estimates, boxplots and heatmaps. All generated heatmaps were ordered according to the following signatures: 1) BRS, 2) Consensus MIBC, 3) TCGA, 4) Lund and 5) MDA subtypes.

\section{Code availability}

Coefficients of the BRS classifier and datasets are found in the $R$ package on GitHub (https://github.com/CostelloLab/BRSpred) and supplied in the supplementary data. Gene expression data matrices can be supplied to the BRS classifier. If missing genes are detected, mean values are imputed.

\section{Immunohistochemistry}

Sections were obtained from the same FFPE blocks as used for RNA isolation. Immunohistochemistry was performed according to the BenchMark ULTRA (Ventana) protocol. Sections were deparaffinated and washed (EZ Prep, Ventan). Heating and incubation was performed according to the Ultra-CC1 condition (Cell Conditioning 1, Ventana, 32 minutes at $100{ }^{\circ} \mathrm{C}$ ) with Reaction Buffer (10X, Tris-based buffer solution ( $\left.\mathrm{pH} 7.6+/-0.2\right)$ washing steps. Next, the primary diagnostics-approved antibody (anti-CD8, clone SP57, Ventana) was added and incubated $\left(32\right.$ minutes at $36{ }^{\circ} \mathrm{C}$ ). Antibody detection was done with the OptiView DAB IHC Detection Kit according to standard diagnostics protocol. For analyses, two independent researchers selected up to six regions surrounding the macrodissected areas used for RNA-sequencing, and counted the CD8+ positive T cells within a single microscopic high-powered field (40x). Boxplots were generated from the mean number of CD8+ positive $T$ cells of up to twelve regions (six regions times two investigators). Wilcoxon testing was done, with statistical significance set at $p<0.05$.

\section{Spatial Proteomics}

Multispectral imaging was done using the Akoya Vectra Polaris instrument at the Human Immune Monitoring Shared Resource (HIMSR) at the University of Colorado Anschutz Medical Campus. Tissue sections from the same tumor blocks as used for RNA-isolation were stained consecutively with specific primary antibodies according to standard protocols provided by Akoya and performed routinely by the HIMSR. Briefly, the slides were deparaffinized, heat treated in antigen retrieval buffer, blocked, and incubated with primary antibodies for CD19, CD4, CD11C, FOXP3, CSFR1 (CD115), CD14, Vimentin, and pan-CK followed by horseradish peroxidase (HRP)-conjugated secondary antibody polymer, and HRP-reactive OPAL fluorescent reagents. To prevent further deposition of fluorescent dyes in subsequent staining steps, the slides were stripped in between each stain with heat treatment in antigen retrieval buffer. Whole slide scans were collected using the 10x objective with a 1 micron resolution. Regions of interest surrounding the macrodissected areas used for RNAsequencing were selected for multispectral imaging and quantification tumor areas $(3-28$ fields per tissue, depending on tissue size). Multispectral imaging was performed using the 20x objective with a 0.5 micron resolution. The 9 color images were analyzed with inForm software version 2.5.1 (Akoya Biosciences) to unmix adjacent fluorochromes, subtract autofluorescence, segment tumor and stroma regions of the tissue, segment cellular compartments, and phenotype infiltrating cells according to cell marker expression. Trained phenotyping algorithms developed in inForm for each marker were applied across the entire image set and data were compiled and summarized using Phenoptr Reports software. Summarized findings for intratumoral regions were visualized with boxplots and heatmaps. Wilcoxon tests were used to compare groups, with a two-sided statistical significance threshold of $p<0.05$. 
medRxiv preprint doi: https://doi.org/10.1101/2021.11.30.21266988; this version posted December 5, 2021. The copyright holder for this preprint (which was not certified by peer review) is the author/funder, who has granted medRxiv a license to display the preprint in It is made available under a CC-BY-NC 4.0 International license.

\section{Quantative Signaling Pathway Assay}

625 All pre-BCG samples for Cohort A were used for the RT-qPCR quantitative signal transduction 626 assay (OncoSignal®). Five out of 132 samples failed due to depleted RNA. Samples were 627 checked for RNA integrity and possible PCR disturbing contaminants via performing control 628 PCRs on a number of reference genes. Samples that passed incoming Quality Control were 629 processed further and the activity of ER, AR, MAPK, PI3K, HH, Notch and TGFb pathways 630 were measured. In short: $90 \mu \mathrm{l}$ Purified and DNase treated RNA of tumor tissue is mixed with 631 One-step RT-qPCR reagents (SuperScript III Platinum One-Step qRT-PCR Kit (Thermo 632 Fisher Scientific, cat.no. 11732088) and Nuclease-free water according to the manufacturer's 633 instructions. $25 \mu \mathrm{l}$ of this mix was added to each well of a 96 wells OncoSignal Testing Plate 634 after which the plate is sealed. Each well contains dried-down primers and probes to 635 specifically amplify and detect one of the target genes. The PCR cycling and detection was 636 performed in a Bio-Rad CFX96 (Touch) Real-Time PCR Detection System according to the 637 following protocol: $30^{\prime} 50^{\circ} \mathrm{C}$ for reverse transcription followed by initial denaturation at $95^{\circ} \mathrm{C}$ 638 for $5^{\prime}$ and 45 cycles of denaturation $\left(15^{\prime \prime} 95^{\circ}\right)$ and annealing $\left(30^{\prime \prime} 60^{\circ} \mathrm{C}\right)$. The raw fluorescence 639 data were exported from the Bio-Rad device and uploaded into the Pathway Activity software 640 to calculate the 7 pathway activity scores for every sample. Finally, samples were labeled 641 according to the generated molecular subtypes and visualized with the use of boxplots for all 642 pathways. $P$-values are based on Wilcoxon testing. A logistic regression model was generated 643 to identify BRS3 vs BRS1/2 patients. Sensitivity, specificity and the area under the curve were 644 calculated using the pROC package [87]. 
medRxiv preprint doi: https://doi.org/10.1101/2021.11.30.21266988; this version posted December 5, 2021. The copyright holder for this preprint (which was not certified by peer review) is the author/funder, who has granted medRxiv a license to display the preprint in

It is made available under a CC-BY-NC 4.0 International license .

\section{Supplementary Materials:}

646

647

648

649

650

651

652

653

654

655

656

657

658

659

660

661

662

663

664

665

666

667

668

669

670

671

672

673

674

675

676

677

678

679

680

681

682

683

684

685

686

687

688

689

690

691

692

- Materials and methods

- Fig. S1. Consensus clustering results, Kaplan-Meier estimates of survival and gene signatures associated with BCG response subtypes (BRS) in the training and testing set in Cohort A.

- Fig. S2. Single nucleotide variant analysis for BCG response subtypes in Cohort A.

- Fig. S3. Heatmap of predicted BCG response subtypes in Cohort B.

- Fig. S4. Signatures and progression-free survival of BCG response subtypes in external cohorts.

- Fig. S5. BCG response subtype analyses in patients who had undergone a re-TURBT in Cohort A.

- Fig. S6. Heatmap of signature genes for BCG response subtypes, lumfFiinal gene set enrichment in BRS2 and regulon analysis. Result based on combination of Cohort A+B.

- Fig. S7. Nomogram to improve risk stratification in HR-NMIBC and OncoSignals $®$ pathway results.

- Fig. S8. Kaplan-Meier estimates of Progression-Free Survival (PFS) based on currently published (N)MIBC molecular subtypes (Cohort A+B combined).

- Fig. S9. Gene fusions, gene set enrichment analysis and single-nucleotide variants in $n=34$ paired pre- and post-BCG tumors from $n=34$ HR-NMIBC patients.

- Table S1: Resources \& clinical data

- Table S2: Transcriptomic SNVs results

- Table S3: Differentially expressed genes

- Table S4: Pathway \& VIPER analyses

- Table S5: Immune deconvolution results

- Table S6: Paired pre- vs post-BCG analyses

- Table S7: Gene fusions in the paired sample analysis

- Data file S1: Normalized gene expression table BCG-naive Cohort A+B

- Data file S2: Raw counts Cohort A and Cohort B

- Data file S3: PAMR classifier coefficients

\section{Acknowledgements:}

FC de Jong expresses his deep gratitude to the Dutch Foundation "De Drie Lichten", which supports medical research at the University of Colorado Anschutz Medical Campus, Aurora, CO, USA. The authors express their gratitude to Vebjørn Kvikstad, Jolien Mensink, Sébastien Rinaldetti and Joep de Jong for their help with patient data collection and analyses. This work utilized the Biostatistics and Bioinformatics Shared Resource and the Human Immune Monitoring Shared Resource supported by CA046934. Finally, we thank Lars Dyrskjøt for providing us with the raw count tables of the UROMOL21 dataset.

Funding: This work was generously supported by MRACE Grant no.107477 (TZ), the Anschutz Foundation (JCC, DT), FICAN Cancer Researcher by the Finnish Cancer Institute (TDL), and in part from CA075115 (DT).

\section{Author Contributions:}

Conceptualization: FCJ, DTL, JCC, and TZ

Methodology: FCJ, TDL, DT, TZ and JCC

Formal analysis FCJ, TDL and JCC

Investigation: FCJ, TDL, $\mathrm{RH}$ and $\mathrm{AM}$

Resources: RH, KJ, EJ, EB, DS, BN, EJ, JLB, DT, and TZ

Data curation: FCJ, TDL and AM

Writing-original draft preparation: FCJ

Writing-review and editing: FCJ, TM, JLB, DT, JCC and TZ

Supervision: DT, JCC and TZ

Project administration: JCC and TZ

Funding acquisition: DT, JCC and TZ 
medRxiv preprint doi: https://doi.org/10.1101/2021.11.30.21266988; this version posted December 5, 2021. The copyright holder for this preprint (which was not certified by peer review) is the author/funder, who has granted medRxiv a license to display the preprint in It is made available under a CC-BY-NC 4.0 International license.

\section{Competing interests:}

$694 \mathrm{JCC}$ is co-founder of PrecisionProfile. None of the contributing authors have any competing interests, 695 including specific financial interests and relationships and affiliations relevant to the subject matter in 696 the manuscript.

\section{Data and materials availability}

698 A detailed overview of all resources including assays, commercial systems and companies, software, 699 critical $R$ packages including versions and associated references used in this manuscript are in Table 700 S1. The total clinical data table is included as Table S1 as well. Raw data will be deposited for public use in the European Genome-Phenome Archive upon paper acceptance. 
medRxiv preprint doi: https://doi.org/10.1101/2021.11.30.21266988; this version posted December 5, 2021. The copyright holder for this preprint (which was not certified by peer review) is the author/funder, who has granted medRxiv a license to display the preprint in perpetuity.

It is made available under a CC-BY-NC 4.0 International license.

\section{References and Notes}

1. Babjuk, M., M. Burger, O. Capoun, D. Cohen, E. M. Compérat, J. L. Dominguez Escrig, P. Gontero, F. Liedberg, A. Masson-Lecomte, A. H. Mostafid, J. Palou, B. W. G. van Rhijn, M. Rouprêt, S. F. Shariat, T. Seisen, V. Soukup, and R. J. Sylvester. "European Association of Urology Guidelines on Non-Muscle-Invasive Bladder Cancer (Ta, T1, and Carcinoma in Situ)." Eur Urol (2021).

2. Oddens, J., M. Brausi, R. Sylvester, A. Bono, C. van de Beek, G. van Andel, P. Gontero, W. Hoeltl, L. Turkeri, S. Marreaud, S. Collette, and W. Oosterlinck. "Final Results of an Eortc-Gu Cancers Group Randomized Study of Maintenance Bacillus Calmette-Guérin in Intermediateand High-Risk Ta, T1 Papillary Carcinoma of the Urinary Bladder: One-Third Dose Versus Full Dose and 1 Year Versus 3 Years of Maintenance." Eur Urol 63, no. 3 (2013): 462-72.

3. de Jong, F. C., R. F. Hoedemaeker, V. Kvikstad, J. T. M. Mensink, J. J. de Jong, E. R. Boevé, D. K. E. van der Schoot, E. C. Zwarthoff, J. L. Boormans, and T. C. M. Zuiverloon. "T1 Substaging of Nonmuscle Invasive Bladder Cancer Is Associated with Bacillus Calmette-Guérin Failure and Improves Patient Stratification at Diagnosis." J Urol (2020): 101097ju0000000000001422.

4. Ge, Peng, Li Wang, Meng Lu, Lijun Mao, Wang Li, Rumin Wen, Jian Lin, Junqi Wang, and Jiacun Chen. "Oncological Outcome of Primary and Secondary Muscle-Invasive Bladder Cancer: A Systematic Review and Meta-Analysis." Scientific reports 8, no. 1 (2018): 7543-43.

5. Pietzak, E. J., E. C. Zabor, A. Bagrodia, J. Armenia, W. Hu, A. Zehir, S. Funt, F. Audenet, D. Barron, N. Maamouri, Q. Li, M. Y. Teo, M. E. Arcila, M. F. Berger, N. Schultz, G. Dalbagni, H. W. Herr, D. F. Bajorin, J. E. Rosenberg, H. Al-Ahmadie, B. H. Bochner, D. B. Solit, and G. Iyer. "Genomic Differences between "Primary" and "Secondary" Muscle-Invasive Bladder Cancer as a Basis for Disparate Outcomes to Cisplatin-Based Neoadjuvant Chemotherapy." Eur Urol 75, no. 2 (2019): 231-39.

6. Kamat, A. M., R. Li, M. A. O'Donnell, P. C. Black, M. Roupret, J. W. Catto, E. Comperat, M. A. Ingersoll, W. P. Witjes, D. J. McConkey, and J. A. Witjes. "Predicting Response to Intravesical Bacillus Calmette-Guérin Immunotherapy: Are We There Yet? A Systematic Review." Eur Urol 73, no. 5 (2018): 738-48.

7. Zuiverloon, T. C., A. J. Nieuweboer, H. Vekony, W. J. Kirkels, C. H. Bangma, and E. C. Zwarthoff. "Markers Predicting Response to Bacillus Calmette-Guerin Immunotherapy in HighRisk Bladder Cancer Patients: A Systematic Review." European urology (2011).

8. Klaassen, Zachary, Ashish M. Kamat, Wassim Kassouf, Paolo Gontero, Humberto Villavicencio, Joaquim Bellmunt, Bas W. G. van Rhijn, Arndt Hartmann, James W. F. Catto, and Girish S. Kulkarni. "Treatment Strategy for Newly Diagnosed T1 High-Grade Bladder Urothelial Carcinoma: New Insights and Updated Recommendations." European Urology 74, no. 5 (2018): 597-608.

9. Mostafid, A. H., J. Palou Redorta, R. Sylvester, and J. A. Witjes. "Therapeutic Options in HighRisk Non-Muscle-Invasive Bladder Cancer During the Current Worldwide Shortage of Bacille Calmette-Guerin." Eur Urol 67, no. 3 (2015): 359-60.

10. Chabanon, Roman M., Mathieu Rouanne, Christopher J. Lord, Jean-Charles Soria, Philippe Pasero, and Sophie Postel-Vinay. "Targeting the DNA Damage Response in ImmunoOncology: Developments and Opportunities." Nature Reviews Cancer (2021).

11. Zhao, Shuang G., William S. Chen, Rajdeep Das, S. Laura Chang, Scott A. Tomlins, Jonathan Chou, David A. Quigley, Ha X. Dang, Travis J. Barnard, Brandon A. Mahal, Ewan A. Gibb, Yang Liu, Elai Davicioni, Linda R. Duska, Edwin M. Posadas, Shruti Jolly, Daniel E. Spratt, Paul L. Nguyen, Christopher A. Maher, Eric J. Small, and Felix Y. Feng. "Clinical and Genomic Implications of Luminal and Basal Subtypes across Carcinomas." Clinical Cancer Research 25, no. 8 (2019): 2450-57.

12. Hurst, Carolyn D., Olivia Alder, Fiona M. Platt, Alastair Droop, Lucy F. Stead, Julie E. Burns, George J. Burghel, Sunjay Jain, Leszek J. Klimczak, Helen Lindsay, Jo-An Roulson, Claire F. Taylor, Helene Thygesen, Angus J. Cameron, Anne J. Ridley, Helen R. Mott, Dmitry A. Gordenin, and Margaret A. Knowles. "Genomic Subtypes of Non-Invasive Bladder Cancer with Distinct Metabolic Profile and Female Gender Bias in Kdm6a Mutation Frequency." Cancer Cell 32, no. 5 (2017): 701-15.e7.

13. Lindskrog, Sia Viborg, Frederik Prip, Philippe Lamy, Ann Taber, Clarice S. Groeneveld, Karin Birkenkamp-Demtröder, Jørgen Bjerggaard Jensen, Trine Strandgaard, Iver Nordentoft, Emil Christensen, Mateo Sokac, Nicolai J. Birkbak, Lasse Maretty, Gregers G. Hermann, Astrid C. Petersen, Veronika Weyerer, Marc-Oliver Grimm, Marcus Horstmann, Gottfrid Sjödahl, Mattias Höglund, Torben Steiniche, Karin Mogensen, Aurélien de Reyniès, Roman Nawroth, Brian Jordan, Xiaoqi Lin, Dejan Dragicevic, Douglas G. Ward, Anshita Goel, Carolyn D. Hurst, Jay D. 
medRxiv preprint doi: https://doi.org/10.1101/2021.11.30.21266988; this version posted December 5, 2021. The copyright holder for this preprint (which was not certified by peer review) is the author/funder, who has granted medRxiv a license to display the preprint in perpetuity.

It is made available under a CC-BY-NC 4.0 International license.

Raman, Joshua I. Warrick, Ulrika Segersten, Danijel Sikic, Kim E. M. van Kessel, Tobias Maurer, Joshua J. Meeks, David J. DeGraff, Richard T. Bryan, Margaret A. Knowles, Tatjana Simic, Arndt Hartmann, Ellen C. Zwarthoff, Per-Uno Malmström, Núria Malats, Francisco X. Real, and Lars Dyrskjøt. "An Integrated Multi-Omics Analysis Identifies Prognostic Molecular Subtypes of Non-Muscle-Invasive Bladder Cancer." Nature Communications 12, no. 1 (2021): 2301.

14. Marzouka, Nour-al-dain, Pontus Eriksson, Carlos Rovira, Fredrik Liedberg, Gottfrid Sjödahl, and Mattias Höglund. "A Validation and Extended Description of the Lund Taxonomy for Urothelial Carcinoma Using the Tcga Cohort." Scientific reports 8, no. 1 (2018): 3737.

15. Dyrskjot, L., T. Reinert, F. Algaba, E. Christensen, D. Nieboer, G. G. Hermann, K. Mogensen, W. Beukers, M. Marquez, U. Segersten, S. Hoyer, B. P. Ulhoi, A. Hartmann, R. Stohr, S. Wach, R. Nawroth, K. Schwamborn, C. Tulic, T. Simic, K. Junker, N. Harving, A. C. Petersen, J. B. Jensen, B. Keck, M. O. Grimm, M. Horstmann, T. Maurer, E. W. Steyerberg, E. C. Zwarthoff, F. X. Real, N. Malats, P. U. Malmstrom, and T. F. Orntoft. "Prognostic Impact of a 12-Gene Progression Score in Non-Muscle-Invasive Bladder Cancer: A Prospective Multicentre Validation Study." Eur Urol 72, no. 3 (2017): 461-69.

16. Kim, Y. J., Y. S. Ha, S. K. Kim, H. Y. Yoon, M. S. Lym, M. J. Kim, S. K. Moon, Y. H. Choi, and W. J. Kim. "Gene Signatures for the Prediction of Response to Bacillus Calmette-Guerin Immunotherapy in Primary Pt1 Bladder Cancers." Clin Cancer Res 16, no. 7 (2010): 2131-7.

17. Robertson, A. G., C. S. Groeneveld, B. Jordan, X. Lin, K. A. McLaughlin, A. Das, L. A. Fall, D. Fantini, T. J. Taxter, L. S. Mogil, S. V. Lindskrog, L. Dyrskjøt, D. J. McConkey, R. S. Svatek, A. de Reyniès, M. A. A. Castro, and J. J. Meeks. "Identification of Differential Tumor Subtypes of T1 Bladder Cancer." Eur Urol (2020).

18. Robertson, A. G., J. Kim, H. Al-Ahmadie, J. Bellmunt, G. Guo, A. D. Cherniack, T. Hinoue, P. W. Laird, K. A. Hoadley, R. Akbani, M. A. A. Castro, E. A. Gibb, R. S. Kanchi, D. A. Gordenin, S. A. Shukla, F. Sanchez-Vega, D. E. Hansel, B. A. Czerniak, V. E. Reuter, X. Su, B. de Sa Carvalho, V. S. Chagas, K. L. Mungall, S. Sadeghi, C. S. Pedamallu, Y. Lu, L. J. Klimczak, J. Zhang, C. Choo, A. I. Ojesina, S. Bullman, K. M. Leraas, T. M. Lichtenberg, C. J. Wu, N. Schultz, G. Getz, M. Meyerson, G. B. Mills, D. J. McConkey, J. N. Weinstein, D. J. Kwiatkowski, and S. P. Lerner. "Comprehensive Molecular Characterization of Muscle-Invasive Bladder Cancer." Cell 171, no. 3 (2017): 540-56.e25.

19. Dyrskjot, L., K. Zieger, F. X. Real, N. Malats, A. Carrato, C. Hurst, S. Kotwal, M. Knowles, P. U. Malmstrom, M. de la Torre, K. Wester, Y. Allory, D. Vordos, A. Caillault, F. Radvanyi, A. M. Hein, J. L. Jensen, K. M. Jensen, N. Marcussen, and T. F. Orntoft. "Gene Expression Signatures Predict Outcome in Non-Muscle-Invasive Bladder Carcinoma: A Multicenter Validation Study." Clin Cancer Res 13, no. 12 (2007): 3545-51.

20. Damrauer, Jeffrey S., Katherine A. Hoadley, David D. Chism, Cheng Fan, Christopher J. Tiganelli, Sara E. Wobker, Jen Jen Yeh, Matthew I. Milowsky, Gopa lyer, Joel S. Parker, and William Y. Kim. "Intrinsic Subtypes of High-Grade Bladder Cancer Reflect the Hallmarks of Breast Cancer Biology." Proceedings of the National Academy of Sciences of the United States of America 111, no. 8 (2014): 3110-15.

21. Choi, W., S. Porten, S. Kim, D. Willis, E. R. Plimack, J. Hoffman-Censits, B. Roth, T. Cheng, M. Tran, I. L. Lee, J. Melquist, J. Bondaruk, T. Majewski, S. Zhang, S. Pretzsch, K. Baggerly, A. Siefker-Radtke, B. Czerniak, C. P. Dinney, and D. J. McConkey. "Identification of Distinct Basal and Luminal Subtypes of Muscle-Invasive Bladder Cancer with Different Sensitivities to Frontline Chemotherapy." Cancer Cell 25, no. 2 (2014): 152-65.

22. Naselli, A., R. Hurle, S. Paparella, N. M. Buffi, G. Lughezzani, G. Lista, P. Casale, A. Saita, M. Lazzeri, and G. Guazzoni. "Role of Restaging Transurethral Resection for T1 Non-Muscle Invasive Bladder Cancer: A Systematic Review and Meta-Analysis." Eur Urol Focus 4, no. 4 (2018): 558-67.

23. Kates, Max, Andres Matoso, Woonyoung Choi, Alexander S. Baras, Marcus J. Daniels, Kara Lombardo, Aaron Brant, Nina Mikkilineni, David J. McConkey, Ashish M. Kamat, Robert S. Svatek, Sima P. Porten, Joshua J. Meeks, Seth P. Lerner, Colin P. Dinney, Peter C. Black, James M. McKiernan, Chris Anderson, Charles G. Drake, and Trinity J. Bivalacqua. "Adaptive Immune Resistance to Intravesical Bcg in Non-Muscle Invasive Bladder Cancer: Implications for Prospective Bcg-Unresponsive Trials." Clinical Cancer Research 26, no. 4 (2020): 882-91.

24. Alvarez, Mariano J., Yao Shen, Federico M. Giorgi, Alexander Lachmann, B. Belinda Ding, B. Hilda Ye, and Andrea Califano. "Functional Characterization of Somatic Mutations in Cancer Using Network-Based Inference of Protein Activity." Nature genetics 48, no. 8 (2016): 838-47.

25. Finan, Chris, Anna Gaulton, Felix A. Kruger, R. Thomas Lumbers, Tina Shah, Jorgen Engmann, Luana Galver, Ryan Kelley, Anneli Karlsson, Rita Santos, John P. Overington, Aroon D. Hingorani, and Juan P. Casas. "The Druggable Genome and Support for Target Identification 
medRxiv preprint doi: https://doi.org/10.1101/2021.11.30.21266988; this version posted December 5, 2021. The copyright holder for this preprint (which was not certified by peer review) is the author/funder, who has granted medRxiv a license to display the preprint in perpetuity.

It is made available under a CC-BY-NC 4.0 International license.

and Validation in Drug Development." Science Translational Medicine 9, no. 383 (2017): eaag1166.

26. Urist, Marshall J., Charles J. Di Como, Ming-Lan Lu, Elizabeth Charytonowicz, David Verbel, Christopher P. Crum, Tan A. Ince, Frank D. McKeon, and Carlos Cordon-Cardo. "Loss of P63 Expression Is Associated with Tumor Progression in Bladder Cancer." The American journal of pathology 161, no. 4 (2002): 1199-206.

27. Liberzon, Arthur, Chet Birger, Helga Thorvaldsdóttir, Mahmoud Ghandi, Jill P Mesirov, and Pablo Tamayo. "The Molecular Signatures Database Hallmark Gene Set Collection." Cell Systems 1, no. 6 (2015): 417-25.

28. Yoshihara, Kosuke, Maria Shahmoradgoli, Emmanuel Martínez, Rahulsimham Vegesna, Hoon Kim, Wandaliz Torres-Garcia, Victor Treviño, Hui Shen, Peter W. Laird, Douglas A. Levine, Scott L. Carter, Gad Getz, Katherine Stemke-Hale, Gordon B. Mills, and Roel G. W. Verhaak. "Inferring Tumour Purity and Stromal and Immune Cell Admixture from Expression Data." Nature Communications 4, no. 1 (2013): 2612.

29. Finotello, Francesca, Clemens Mayer, Christina Plattner, Gerhard Laschober, Dietmar Rieder, Hubert Hackl, Anne Krogsdam, Zuzana Loncova, Wilfried Posch, Doris Wilflingseder, Sieghart Sopper, Marieke ljsselsteijn, Thomas P. Brouwer, Douglas Johnson, Yaomin Xu, Yu Wang, Melinda E. Sanders, Monica V. Estrada, Paula Ericsson-Gonzalez, Pornpimol Charoentong, Justin Balko, Noel Filipe da Cunha Carvalho de Miranda, and Zlatko Trajanoski. "Molecular and Pharmacological Modulators of the Tumor Immune Contexture Revealed by Deconvolution of Rna-Seq Data." Genome Medicine 11, no. 1 (2019): 34.

30. Racle, J., and D. Gfeller. "Epic: A Tool to Estimate the Proportions of Different Cell Types from Bulk Gene Expression Data." Methods Mol Biol 2120 (2020): 233-48.

31. Chen, Binbin, Michael S. Khodadoust, Chih Long Liu, Aaron M. Newman, and Ash A. Alizadeh. "Profiling Tumor Infiltrating Immune Cells with Cibersort." Methods in molecular biology (Clifton, N.J.) 1711 (2018): 243-59.

32. Ratliff, T. L., J. K. Ritchey, J. J. Yuan, G. L. Andriole, and W. J. Catalona. "T-Cell Subsets Required for Intravesical Bcg Immunotherapy for Bladder Cancer." J Urol 150, no. 3 (1993): 1018-23.

33. Biot, C., C. A. Rentsch, J. R. Gsponer, F. D. Birkhäuser, H. Jusforgues-Saklani, F. Lemaître, C. Auriau, A. Bachmann, P. Bousso, C. Demangel, L. Peduto, G. N. Thalmann, and M. L. Albert. "Preexisting Bcg-Specific T Cells Improve Intravesical Immunotherapy for Bladder Cancer." Sci Transl Med 4, no. 137 (2012): 137ra72.

34. Kates, Max, Thomas Nirschl, Nikolai A. Sopko, Hotaka Matsui, Christina M. Kochel, Leonardo O. Reis, George J. Netto, Mohammad O. Hoque, Noah M. Hahn, David J. McConkey, Alex S. Baras, Charles G. Drake, and Trinity J. Bivalacqua. "Intravesical Bcg Induces Cd4<Sup $>+</$ Sup $>$ T-Cell Expansion in an Immune Competent Model of Bladder Cancer." Cancer Immunology Research 5, no. 7 (2017): 594-603.

35. Chevalier, Mathieu F., Anna K. Schneider, Valerie Cesson, Florence Dartiguenave, llaria Lucca, Patrice Jichlinski, Denise Nardelli-Haefliger, and Laurent Derré. "Conventional and PdL1-Expressing Regulatory T Cells Are Enriched During Bcg Therapy and May Limit Its Efficacy." European Urology 74, no. 5 (2018): 540-44.

36. Kamat, A. M., R. J. Sylvester, A. Bohle, J. Palou, D. L. Lamm, M. Brausi, M. Soloway, R. Persad, R. Buckley, M. Colombel, and J. A. Witjes. "Definitions, End Points, and Clinical Trial Designs for Non-Muscle-Invasive Bladder Cancer: Recommendations from the International Bladder Cancer Group." J Clin Oncol 34, no. 16 (2016): 1935-44.

37. van de Stolpe, Anja, Wim Verhaegh, Jean-Yves Blay, Cynthia X. Ma, Patrick Pauwels, Mark Pegram, Hans Prenen, Dirk De Ruysscher, Nabil F. Saba, Susan F. Slovin, Karen WillardGallo, and Hatim Husain. "Rna Based Approaches to Profile Oncogenic Pathways from Low Quantity Samples to Drive Precision Oncology Strategies." Frontiers in Genetics 11, no. 1715 (2021).

38. Sottnik, J. L., and D. Theodorescu. "Cd44: A Metastasis Driver and Therapeutic Target." Oncoscience 3, no. 11-12 (2016): 320-21.

39. Ahmed, Mansoor, Joseph L. Sottnik, Garrett M. Dancik, Divya Sahu, Donna E. Hansel, Dan Theodorescu, and Martin A. Schwartz. "An Osteopontin/Cd44 Axis in Rhogdi2-Mediated Metastasis Suppression." Cancer Cell 30, no. 3 (2016): 432-43.

40. Campion, C. G., M. Labrie, G. Lavoie, and Y. St-Pierre. "Expression of Galectin-7 Is Induced in Breast Cancer Cells by Mutant P53." PLoS One 8, no. 8 (2013): e72468.

41. Tu, M. M., F. Y. F. Lee, R. T. Jones, A. K. Kimball, E. Saravia, R. F. Graziano, B. Coleman, K. Menard, J. Yan, E. Michaud, H. Chang, H. A. Abdel-Hafiz, A. I. Rozhok, J. E. Duex, N. Agarwal, A. Chauca-Diaz, L. K. Johnson, T. L. Ng, J. C. Cambier, E. T. Clambey, J. C. Costello, A. J. 
medRxiv preprint doi: https://doi.org/10.1101/2021.11.30.21266988; this version posted December 5, 2021. The copyright holder for this preprint (which was not certified by peer review) is the author/funder, who has granted medRxiv a license to display the preprint in perpetuity.

It is made available under a CC-BY-NC 4.0 International license.

Korman, and D. Theodorescu. "Targeting Ddr2 Enhances Tumor Response to Anti-Pd-1 Immunotherapy." Sci Adv 5, no. 2 (2019): eaav2437.

42. Said, N., M. Sanchez-Carbayo, S. C. Smith, and D. Theodorescu. "Rhogdi2 Suppresses Lung Metastasis in Mice by Reducing Tumor Versican Expression and Macrophage Infiltration." $J$ Clin Invest 122, no. 4 (2012): 1503-18.

43. Calvete, J., G. Larrinaga, P. Errarte, A. M. Martín, A. Dotor, C. Esquinas, C. E. Nunes-Xavier, R. Pulido, J. I. López, and J. C. Angulo. "The Coexpression of Fibroblast Activation Protein (Fap) and Basal-Type Markers (Ck 5/6 and Cd44) Predicts Prognosis in High-Grade Invasive Urothelial Carcinoma of the Bladder." Hum Pathol 91 (2019): 61-68.

44. Nathan, Elisha, and Eldad Tzahor. "Sfrps: A Declaration of (Wnt) Independence." Nature Cell Biology 11, no. 1 (2009): 13-13.

45. Pichler, R., J. Fritz, C. Zavadil, G. Schafer, Z. Culig, and A. Brunner. "Tumor-Infiltrating Immune Cell Subpopulations Influence the Oncologic Outcome after Intravesical Bacillus CalmetteGuerin Therapy in Bladder Cancer." Oncotarget 7, no. 26 (2016): 39916-30.

46. Pichler, Renate, Georg Gruenbacher, Zoran Culig, Andrea Brunner, Dietmar Fuchs, Josef Fritz, Hubert Gander, Andrea Rahm, and Martin Thurnher. "Intratumoral Th2 Predisposition Combines with an Increased Th1 Functional Phenotype in Clinical Response to Intravesical Bcg in Bladder Cancer." Cancer Immunology, Immunotherapy 66, no. 4 (2017): 427-40.

47. Pettenati, C., and M. A. Ingersoll. "Mechanisms of Bcg Immunotherapy and Its Outlook for Bladder Cancer." Nat Rev Urol 15, no. 10 (2018): 615-25.

48. Koch, Meghan A., Glady's Tucker-Heard, Nikole R. Perdue, Justin R. Killebrew, Kevin B. Urdahl, and Daniel J. Campbell. "The Transcription Factor T-Bet Controls Regulatory T Cell Homeostasis and Function During Type 1 Inflammation." Nature Immunology 10, no. 6 (2009): 595-602.

49. de Reijke, T. M., E. C. de Boer, K. H. Kurth, and D. H. Schamhart. "Urinary Cytokines During Intravesical Bacillus Calmette-Guerin Therapy for Superficial Bladder Cancer: Processing, Stability and Prognostic Value." J Urol 155, no. 2 (1996): 477-82.

50. Fleischmann, J. D., Z. Toossi, J. J. Ellner, D. B. Wentworth, T. L. Ratliff, and A. L. Imbembo. "Urinary Interleukins in Patients Receiving Intravesical Bacillus Calmette-Guerin Therapy for Superficial Bladder Cancer." Cancer 64, no. 7 (1989): 1447-54.

51. Mahmud, Shawn A., Luke S. Manlove, and Michael A. Farrar. "Interleukin-2 and Stat5 in Regulatory T Cell Development and Function." JAK-STAT2, no. 1 (2013): e23154-e54.

52. Blank, Christian U., W. Nicholas Haining, Werner Held, Patrick G. Hogan, Axel Kallies, Enrico Lugli, Rachel C. Lynn, Mary Philip, Anjana Rao, Nicholas P. Restifo, Andrea Schietinger, Ton N. Schumacher, Pamela L. Schwartzberg, Arlene H. Sharpe, Daniel E. Speiser, E. John Wherry, Benjamin A. Youngblood, and Dietmar Zehn. "Defining 'T Cell Exhaustion'." Nature Reviews Immunology 19, no. 11 (2019): 665-74.

53. Khan, N., A. Vidyarthi, M. Amir, K. Mushtaq, and J. N. Agrewala. "T-Cell Exhaustion in Tuberculosis: Pitfalls and Prospects." Crit Rev Microbiol 43, no. 2 (2017): 133-41.

54. Mariathasan, S., S. J. Turley, D. Nickles, A. Castiglioni, K. Yuen, Y. Wang, E. E. Kadel, III, H. Koeppen, J. L. Astarita, R. Cubas, S. Jhunjhunwala, R. Banchereau, Y. Yang, Y. Guan, C. Chalouni, J. Ziai, Y. Şenbabaoğlu, S. Santoro, D. Sheinson, J. Hung, J. M. Giltnane, A. A. Pierce, K. Mesh, S. Lianoglou, J. Riegler, R. A. D. Carano, P. Eriksson, M. Höglund, L. Somarriba, D. L. Halligan, M. S. van der Heijden, Y. Loriot, J. E. Rosenberg, L. Fong, I. Mellman, D. S. Chen, M. Green, C. Derleth, G. D. Fine, P. S. Hegde, R. Bourgon, and T. Powles. "Tgf $\beta$ Attenuates Tumour Response to Pd-L1 Blockade by Contributing to Exclusion of T Cells." Nature 554, no. 7693 (2018): 544-48.

55. Balar, A. V., A. M. Kamat, G. S. Kulkarni, E. M. Uchio, J. L. Boormans, M. Roumiguié, L. E. M. Krieger, E. A. Singer, D. F. Bajorin, P. Grivas, H. K. Seo, H. Nishiyama, B. R. Konety, H. Li, K. Nam, E. Kapadia, T. Frenkl, and R. de Wit. "Pembrolizumab Monotherapy for the Treatment of High-Risk Non-Muscle-Invasive Bladder Cancer Unresponsive to Bcg (Keynote-057): An OpenLabel, Single-Arm, Multicentre, Phase 2 Study." Lancet Oncol 22, no. 7 (2021): 919-30.

56. van Dijk, N., A. Gil-Jimenez, K. Silina, K. Hendricksen, L. A. Smit, J. M. de Feijter, M. L. van Montfoort, C. van Rooijen, D. Peters, A. Broeks, H. G. van der Poel, A. Bruining, Y. Lubeck, K. Sikorska, T. N. Boellaard, P. Kvistborg, D. J. Vis, E. Hooijberg, T. N. Schumacher, M. van den Broek, L. F. A. Wessels, C. U. Blank, B. W. van Rhijn, and M. S. van der Heijden. "Preoperative Ipilimumab Plus Nivolumab in Locoregionally Advanced Urothelial Cancer: The Nabucco Trial." Nat Med (2020).

57. Tu, Megan M., Francis Y. F. Lee, Robert T. Jones, Abigail K. Kimball, Elizabeth Saravia, Robert F. Graziano, Brianne Coleman, Krista Menard, Jun Yan, Erin Michaud, Han Chang, Hany A. Abdel-Hafiz, Andrii I. Rozhok, Jason E. Duex, Neeraj Agarwal, Ana Chauca-Diaz, Linda K. Johnson, Terry L. Ng, John C. Cambier, Eric T. Clambey, James C. Costello, Alan J. Korman, 
medRxiv preprint doi: https://doi.org/10.1101/2021.11.30.21266988; this version posted December 5, 2021. The copyright holder for this preprint (which was not certified by peer review) is the author/funder, who has granted medRxiv a license to display the preprint in perpetuity.

It is made available under a CC-BY-NC 4.0 International license.

and Dan Theodorescu. "Targeting Ddr2 Enhances Tumor Response to Anti-Pd-1 Immunotherapy." Science Advances 5, no. 2 (2019): eaav2437.

58. Tu, M. M., H. A. Abdel-Hafiz, R. T. Jones, A. Jean, K. J. Hoff, J. E. Duex, A. Chauca-Diaz, J. C. Costello, G. M. Dancik, B. A. J. Tamburini, B. Czerniak, J. Kaye, and D. Theodorescu. "Inhibition of the Ccl2 Receptor, Ccr2, Enhances Tumor Response to Immune Checkpoint Therapy." Commun Biol 3, no. 1 (2020): 720.

59. Loureiro, J., and H. L. Ploegh. "Antigen Presentation and the Ubiquitin-Proteasome System in Host-Pathogen Interactions." Adv Immunol 92 (2006): 225-305.

60. van der Woude, A. D., J. Luirink, and W. Bitter. "Getting across the Cell Envelope: Mycobacterial Protein Secretion." Curr Top Microbiol Immunol 374 (2013): 109-34.

61. Wu, S. J., Y. S. Niknafs, S. H. Kim, K. Oravecz-Wilson, C. Zajac, T. Toubai, Y. Sun, J. Prasad, D. Peltier, H. Fujiwara, I. Hedig, N. D. Mathewson, R. Khoriaty, D. Ginsburg, and P. Reddy. "A Critical Analysis of the Role of Snare Protein Sec22b in Antigen Cross-Presentation." Cell Rep 19, no. 13 (2017): 2645-56.

62. Obino, D., J. Diaz, J. J. Sáez, J. Ibañez-Vega, P. J. Sáez, M. Alamo, D. Lankar, and M. I. Yuseff. "Vamp-7-Dependent Secretion at the Immune Synapse Regulates Antigen Extraction and Presentation in B-Lymphocytes." Mol Biol Cell 28, no. 7 (2017): 890-97.

63. Cebrian, I., C. Croce, N. A. Guerrero, N. Blanchard, and L. S. Mayorga. "Rab22a Controls MhcI Intracellular Trafficking and Antigen Cross-Presentation by Dendritic Cells." EMBO Rep 17, no. 12 (2016): 1753-65.

64. Jagannath, Chinnaswamy, Devin R. Lindsey, Subramanian Dhandayuthapani, Yi Xu, Robert L. Hunter, and N. Tony Eissa. "Autophagy Enhances the Efficacy of Bcg Vaccine by Increasing Peptide Presentation in Mouse Dendritic Cells." Nature Medicine 15, no. 3 (2009): 267-76.

65. Gutierrez, M. G., S. S. Master, S. B. Singh, G. A. Taylor, M. I. Colombo, and V. Deretic. "Autophagy Is a Defense Mechanism Inhibiting Bcg and Mycobacterium Tuberculosis Survival in Infected Macrophages." Cell 119, no. 6 (2004): 753-66.

66. Buffen, Kathrin, Marije Oosting, Jessica Quintin, Aylwin Ng, Johanneke Kleinnijenhuis, Vinod Kumar, Esther van de Vosse, Cisca Wijmenga, Reinout van Crevel, Egbert Oosterwijk, Anne J. Grotenhuis, Sita H. Vermeulen, Lambertus A. Kiemeney, Frank L. van de Veerdonk, Georgios Chamilos, Ramnik J. Xavier, Jos W. M. van der Meer, Mihai G. Netea, and Leo A. B. Joosten. "Autophagy Controls Bcg-Induced Trained Immunity and the Response to Intravesical Bcg Therapy for Bladder Cancer." PLOS Pathogens 10, no. 10 (2014): e1004485.

67. de Jong, Joep J., and Ellen C. Zwarthoff. "Molecular and Clinical Heterogeneity within the Luminal Subtype." Nature Reviews Urology 17, no. 2 (2020): 69-70.

68. Mahe, Mélanie, Florent Dufour, Hélène Neyret-Kahn, Aura Moreno-Vega, Claire Beraud, Mingjun Shi, Imene Hamaidi, Virginia Sanchez-Quiles, Clementine Krucker, Marion DorlandGalliot, Elodie Chapeaublanc, Remy Nicolle, Hervé Lang, Celio Pouponnot, Thierry Massfelder, François Radvanyi, and Isabelle Bernard-Pierrot. "An Fgfr3/Myc Positive Feedback Loop Provides New Opportunities for Targeted Therapies in Bladder Cancers." EMBO molecular medicine 10, no. 4 (2018): e8163.

69. Loriot, Y., A. Necchi, S. H. Park, J. Garcia-Donas, R. Huddart, E. Burgess, M. Fleming, A. Rezazadeh, B. Mellado, S. Varlamov, M. Joshi, I. Duran, S. T. Tagawa, Y. Zakharia, B. Zhong, K. Stuyckens, A. Santiago-Walker, P. De Porre, A. O'Hagan, A. Avadhani, and A. O. SiefkerRadtke. "Erdafitinib in Locally Advanced or Metastatic Urothelial Carcinoma." N Engl J Med 381, no. 4 (2019): 338-48.

70. Klepsch, Victoria, Natascha Hermann-Kleiter, Patricia Do-Dinh, Bojana Jakic, Anne Offermann, Mirjana Efremova, Sieghart Sopper, Dietmar Rieder, Anne Krogsdam, Gabriele Gamerith, Sven Perner, Alexandar Tzankov, Zlatko Trajanoski, Dominik Wolf, and Gottfried Baier. "Nuclear Receptor Nr2f6 Inhibition Potentiates Responses to Pd-L1/Pd-1 Cancer Immune Checkpoint Blockade." Nature Communications 9, no. 1 (2018): 1538.

71. Klepsch, Victoria, Maria Pommermayr, Dominik Humer, Natascha Brigo, Natascha HermannKleiter, and Gottfried Baier. "Targeting the Orphan Nuclear Receptor Nr2f6 in T Cells Primes Tumors for Immune Checkpoint Therapy." Cell Communication and Signaling 18, no. 1 (2020): 8.

72. Zou, Sailan, Qiyu Tong, Bowen Liu, Wei Huang, Yan Tian, and Xianghui Fu. "Targeting Stat3 in Cancer Immunotherapy." Molecular cancer 19, no. 1 (2020): 145-45.

73. Mancarella, Serena, Grazia Serino, Francesco Dituri, Antonio Cigliano, Silvia Ribback, Jingxiao Wang, Xin Chen, Diego F. Calvisi, and Gianluigi Giannelli. "Crenigacestat, a Selective Notch1 Inhibitor, Reduces Intrahepatic Cholangiocarcinoma Progression by Blocking Vegfa/DII4/Mmp13 Axis." Cell Death \& Differentiation 27, no. 8 (2020): 2330-43.

74. Johnson, Daniel E., Rachel A. O'Keefe, and Jennifer R. Grandis. "Targeting the II-6/Jak/Stat3 Signalling Axis in Cancer." Nature Reviews Clinical Oncology 15, no. 4 (2018): 234-48. 
medRxiv preprint doi: https://doi.org/10.1101/2021.11.30.21266988; this version posted December 5, 2021. The copyright holder for this preprint (which was not certified by peer review) is the author/funder, who has granted medRxiv a license to display the preprint in

It is made available under a CC-BY-NC 4.0 International license.

75. Matulay, J. T., R. Li, P. J. Hensley, N. A. Brooks, V. M. Narayan, H. B. Grossman, N. Navai, C. P. N. Dinney, and A. M. Kamat. "Contemporary Outcomes of Patients with Nonmuscle-Invasive Bladder Cancer Treated with Bacillus Calmette-Guérin: Implications for Clinical Trial Design." J Urol 205, no. 6 (2021): 1612-21.

76. Thomsen, Mathilde Borg Houlberg, Iver Nordentoft, Philippe Lamy, Søren Vang, Line Reinert, Christophe Kamungu Mapendano, Søren Høyer, Torben F. Ørntoft, Jørgen Bjerggaard Jensen, and Lars Dyrskjøt. "Comprehensive Multiregional Analysis of Molecular Heterogeneity in Bladder Cancer." Scientific Reports 7, no. 1 (2017): 11702.

77. Warrick, J. I., G. Sjödahl, M. Kaag, J. D. Raman, S. Merrill, L. Shuman, G. Chen, V. Walter, and D. J. DeGraff. "Intratumoral Heterogeneity of Bladder Cancer by Molecular Subtypes and Histologic Variants." Eur Urol 75, no. 1 (2019): 18-22.

78. McGranahan, N., and C. Swanton. "Clonal Heterogeneity and Tumor Evolution: Past, Present, and the Future." Cell 168, no. 4 (2017): 613-28.

79. Meeks, Joshua J., Hikmat Al-Ahmadie, Bishoy M. Faltas, John A. Taylor, Thomas W. Flaig, David J. DeGraff, Emil Christensen, Benjamin L. Woolbright, David J. McConkey, and Lars Dyrskjøt. "Genomic Heterogeneity in Bladder Cancer: Challenges and Possible Solutions to Improve Outcomes." Nature Reviews Urology 17, no. 5 (2020): 259-70.

80. Humphrey, P. A., H. Moch, A. L. Cubilla, T. M. Ulbright, and V. E. Reuter. "The 2016 Who Classification of Tumours of the Urinary System and Male Genital Organs-Part B: Prostate and Bladder Tumours." Eur Urol 70, no. 1 (2016): 106-19.

81. Maechler, M., Rousseeuw, P., Struyf, A., Hubert, M., Hornik, K. "Cluster: Cluster Analysis Basics and Extensions " $R$ package Version 2.0.3 (2015).

82. Pagès H, Carlson M, Falcon S, Li N. . "Annotationdbi: Manipulation of Sqlite-Based Annotations in Bioconductor." R package version 1.50 .3 (2020).

83. Wilkerson, Matthew D., and D. Neil Hayes. "Consensusclusterplus: A Class Discovery Tool with Confidence Assessments and Item Tracking." Bioinformatics 26, no. 12 (2010): 1572-73.

84. T. Hastie, R. Tibshirani, B. Narasimhan and G. Chu. "Pamr: Pam: Prediction Analysis for Microarrays. ." R package version 1.56.1 (2019).

85. Kamoun, A., A. de Reyniès, Y. Allory, G. Sjödahl, A. G. Robertson, R. Seiler, K. A. Hoadley, C. S. Groeneveld, H. Al-Ahmadie, W. Choi, M. A. A. Castro, J. Fontugne, P. Eriksson, Q. Mo, J. Kardos, A. Zlotta, A. Hartmann, C. P. Dinney, J. Bellmunt, T. Powles, N. Malats, K. S. Chan, W. Y. Kim, D. J. McConkey, P. C. Black, L. Dyrskjøt, M. Höglund, S. P. Lerner, F. X. Real, and F. Radvanyi. "A Consensus Molecular Classification of Muscle-Invasive Bladder Cancer." Eur Urol 77, no. 4 (2020): 420-33.

86. Dyrskjøt, Lars, Karsten Zieger, Francisco X. Real, Núria Malats, Alfredo Carrato, Carolyn Hurst, Sanjeev Kotwal, Margaret Knowles, Per-Uno Malmström, Manuel de la Torre, Kenneth Wester, Yves Allory, Dimitri Vordos, Aurélie Caillault, François Radvanyi, Anne-Mette K. Hein, Jens L. Jensen, Klaus M.E. Jensen, Niels Marcussen, and Torben F. Ørntoft. "Gene Expression Signatures Predict Outcome in Non-Muscle-Invasive Bladder Carcinoma: A Multicenter Validation Study." Clinical Cancer Research 13, no. 12 (2007): 3545-51.

87. Robin, Xavier, Natacha Turck, Alexandre Hainard, Natalia Tiberti, Frédérique Lisacek, JeanCharles Sanchez, and Markus Müller. "Proc: An Open-Source Package for R and S+ to Analyze and Compare Roc Curves." BMC Bioinformatics 12, no. 1 (2011): 77. 
medRxiv preprint doi: https://doi.org/10.1101/2021.11.30.21266988; this version posted December 5, 2021. The copyright holder for this preprint (which was not certified by peer review) is the author/funder, who has granted medRxiv a license to display the preprint in

Table 1. Baseline patient characteristics and clinical follow-up of all $n=283$ BCG-naive high-risk nonmuscle invasive bladder cancer patients treated with BCG and stratified according to subtype.

\begin{tabular}{|c|c|c|c|c|c|c|}
\hline \multirow{2}{*}{\multicolumn{2}{|c|}{ Patient characteristics ${ }^{a}$}} & \multirow{3}{*}{$\begin{array}{c}\text { All } \\
\boldsymbol{n}(\%) \\
56(80)\end{array}$} & \multirow{4}{*}{$\begin{array}{c}\text { BRS1 } \\
\boldsymbol{n}(\%) \\
70(25) \\
19(7)\end{array}$} & \multirow{4}{*}{$\begin{array}{c}\text { BRS2 } \\
\boldsymbol{n}(\%) \\
90(33) \\
22(8)\end{array}$} & \multirow{4}{*}{$\begin{array}{c}\text { BRS3 } \\
\boldsymbol{n}(\%) \\
67(24) \\
19(5)\end{array}$} & \multirow[t]{2}{*}{$p$} \\
\hline & & & & & & \\
\hline \multirow{2}{*}{ Sex } & male & & & & & \multirow{2}{*}{0.895} \\
\hline & female & $227(20)$ & & & & \\
\hline Age & $\begin{array}{c}\text { Median } \\
\text { (IQR) }\end{array}$ & $70(62-77)$ & $70(62-77)$ & $69(62-76)$ & $71(62-77)$ & 0.826 \\
\hline \multirow{3}{*}{ Smoking } & No & $87(31)$ & $23(8)$ & $36(13)$ & $28(10)$ & \multirow{3}{*}{0.432} \\
\hline & Yes/stopped & $173(61)$ & $61(22)$ & $64(23)$ & $64(17)$ & \\
\hline & Missing & $23(8)$ & $5(2)$ & $12(4)$ & $6(2)$ & \\
\hline \multirow{2}{*}{ re-TURBT } & No & $93(32)$ & $23(8)$ & $37(13)$ & $33(12)$ & \multirow{2}{*}{0.138} \\
\hline & Yes & $190(67)$ & $66(23)$ & $75(27)$ & $49(17)$ & \\
\hline \multirow{3}{*}{ Focality } & Unifocal & $137(48)$ & $43(15)$ & $55(19)$ & $39(14)$ & \multirow{3}{*}{0.772} \\
\hline & Multifocal & $142(50)$ & $46(16)$ & $55(19)$ & $41(14)$ & \\
\hline & Missing & $4(1)$ & $0(0)$ & $2(1)$ & $2(1)$ & \\
\hline \multirow{3}{*}{ Size ${ }^{b}$} & $<3 \mathrm{~cm}$ & $43(15)$ & $16(6)$ & $17(6)$ & $13(4)$ & \multirow{3}{*}{ NA } \\
\hline & $\geq 3 \mathrm{~cm}$ & $46(16)$ & $18(6)$ & $18(6)$ & $7(2)$ & \\
\hline & Missing & 194 (69) & $55(22)$ & $62(24)$ & $13(22)$ & \\
\hline \multirow{2}{*}{ Concomitant CIS } & No & $221(78)$ & $65(23)$ & $93(33)$ & $63(22)$ & \multirow{2}{*}{0.216} \\
\hline & Yes & $62(22)$ & $24(8)$ & $19(7)$ & $19(7)$ & \\
\hline \multirow{3}{*}{ LVI c } & No & $239(84)$ & $76(27)$ & $90(32)$ & $73(26)$ & \multirow{3}{*}{0.417} \\
\hline & Yes & $11(4)$ & $4(1)$ & $4(1)$ & $3(1)$ & \\
\hline & NA & $33(12)$ & $9(3)$ & $18(6)$ & $6(2)$ & \\
\hline \multirow{2}{*}{ Variant histology } & No & $237(83)$ & $71(25)$ & $104(37)$ & $62(22)$ & \multirow{2}{*}{0.002} \\
\hline & Yes & $46(16)$ & $18(6)$ & $8(3)$ & $20(7)$ & \\
\hline \multirow{2}{*}{ EAU Risk group } & High-risk & $124(44)$ & $37(13)$ & $56(19)$ & $31(11)$ & \multirow{2}{*}{0.213} \\
\hline & Highest-risk & $159(56)$ & $52(18)$ & $56(19)$ & $51(18)$ & \\
\hline \multirow{2}{*}{ BCG failure ${ }^{d}$} & No & $156(55)$ & $59(21)$ & $68(24)$ & $29(10)$ & \multirow{2}{*}{$<0.001$} \\
\hline & Yes & $127(45)$ & $30(11)$ & $44(15)$ & $53(19)$ & \\
\hline HG-RFS & 1 year $(\mathrm{Cl})$ & $73(67-78)$ & $77(68-86)$ & $76(68-84)$ & $64(55-76)$ & $<0.001$ \\
\hline \multirow{2}{*}{ Progression } & No & $187(34)$ & $68(24)$ & $80(28)$ & $39(14)$ & \multirow{2}{*}{$<0.001$} \\
\hline & Yes & $96(66)$ & $21(7)$ & $32(11)$ & $43(15)$ & \\
\hline \multirow{2}{*}{ PFS } & 2 year $(\mathrm{Cl})$ & $80(75-84)$ & $88(82-96)$ & $83(76-90)$ & $64(54-76)$ & $<0.001$ \\
\hline & 5 year $(\mathrm{Cl})$ & $70(65-76)$ & $76(64-86)$ & $76(69-85)$ & $55(46-67)$ & $<0.001$ \\
\hline $\begin{array}{l}\text { Follow-up } \\
\text { (months) }\end{array}$ & $\begin{array}{c}\text { Median } \\
(\text { IQR })\end{array}$ & $\begin{array}{c}73(51- \\
104) \\
\end{array}$ & $\begin{array}{c}76(56- \\
103) \\
\end{array}$ & $\begin{array}{c}75(55- \\
104) \\
\end{array}$ & $\begin{array}{c}68(29- \\
100) \\
\end{array}$ & 0.192 \\
\hline
\end{tabular}

$\mathrm{BCG}=$ Bacillus Calmette-Guérin; BRS = BCG Response Subtype; $\mathrm{Cl}=$ confidence interval; $\mathrm{CIS}=$ carcinoma in situ; EAU = European Association of Urology; HG-RFS = high-grade recurrence-free survival; IQR = Interquartile range; NA = not applicable; re-TURBT = repeat transurethral resection of bladder tumor before BCG-induction. ${ }^{\text {a }}$ Percentages may not add up to $100 \%$ due to rounding; ${ }^{\text {b }}$ Not applicable due to missing variables; ${ }^{\mathrm{C}}$ Assessed only in T1 disease; ${ }^{d}$ BCG failure as specified by major urology guidelines, which includes patients with tumors who developed muscle-invasive recurrences, persistent $\mathrm{T} 1 \mathrm{HG}$ after BCG-induction and $\mathrm{HG}$ recurrences after adequate BCG therapy. 